This document is the accepted manuscript version of the following article: Lindner, M., Fitzgerald, J. B., Zimmermann, N. E., Reyer, C., Delzon, S., van der Maaten, E., ... Hanewinke1, M. (2014). Climate change and European forests: what do we know, what are the uncertainties, and what are the implications for forest management? Journal of Environmental Management, 146, 69-83.

https://doi.org/10.1016/j.jenvman . 2014.07.030

\title{
Climate change and European forests: What do we know, what are the uncertainties, and what are the implications for forest management?
}

\author{
Marcus Lindner ${ }^{\mathrm{a}}$, Joanne B. Fitzgerald ${ }^{\mathrm{a}}{ }^{*}$, Niklaus E. Zimmermann ${ }^{\mathrm{b}}$, \\ Christopher Reyer ${ }^{\mathrm{c}, \mathrm{d}}$, Sylvain Delzon ${ }^{\mathrm{e}, \mathrm{f}}$, Ernst van der Maaten ${ }^{\mathrm{g}, \mathrm{h}}$, Mart-Jan Schelhaas ${ }^{\mathrm{i}}$, \\ Petra Lasch ${ }^{\mathrm{c}}$, Jeannette Eggers ${ }^{\mathrm{a}, \mathrm{j}}$, Marieke van der Maaten-Theunissen ${ }^{\mathrm{g}, \mathrm{h}}$, \\ Felicitas Suckow ${ }^{\mathrm{c}}$, Achilleas Psomas ${ }^{\mathrm{b}}$, Benjamin Poulter ${ }^{\mathrm{b}, \mathrm{k}}$, Marc Hanewinkel ${ }^{\mathrm{b}, 1}$ \\ ${ }^{a}$ European Forest Institute, Yliopistokatu 6, 80100 Joensuu, Finland \\ b Swiss Federal Research Institute WSL, Zuercherstrasse 111, CH-8903 Birmensdorf, Switzerland \\ ${ }^{c}$ Potsdam Institute for Climate Impact Research, Telegrafenberg, P.O. Box 601203, 14412 Potsdam, Germany \\ d Department of Geography, Humboldt University Berlin, Berlin, Germany \\ e INRA, UMR1202 BIOGECO, Cestas F-33610, France \\ ${ }^{\mathrm{f}}$ Université de Bordeaux, UMR1202 BIOGECO, Talence F-33400, France \\ g Chair of Forest Growth, Albert-Ludwigs-University Freiburg, Tennenbacher Str. 4, 79106 Freiburg, Germany \\ ${ }^{\mathrm{h}}$ Institute of Botany and Landscape Ecology, University of Greifswald, Soldmannstr. 15, 17487 Greifswald, Germany \\ ${ }^{\mathrm{i}}$ Team Vegetation, Forest and Landscape Ecology, Alterra, Wageningen UR, Netherlands \\ j Department of Forest Resource Management, Swedish University of Agricultural Sciences, Sweden \\ ${ }^{\mathrm{k}}$ Department of Ecology, Montana State University, Bozeman, MT 59715, USA \\ ${ }^{1}$ Forest Research Institute of Baden, Württemberg, Germany
}

\begin{abstract}
The knowledge about potential climate change impacts on forests is continuously expanding and some changes in growth, drought induced mortality and species distribution have been observed. However despite a significant body of research, a knowledge and communication gap exists between scientists and non-scientists as to how climate change impact scenarios can be interpreted and what they imply for European forests. It is still challenging to advise forest decision makers on how best to plan for climate change as many uncertainties and unknowns remain and it is difficult to communicate these to practitioners and other decision makers while retaining emphasis on the importance of planning for adaptation.

In this paper, recent developments in climate change observations and projections, observed and projected impacts on European forests and the associated uncertainties are reviewed and synthesised with a view to understanding the implications for forest management. Current impact assessments with simulation models contain several simplifications, which explain the discrepancy between results of many simulation studies and the rapidly increasing body of evidence about already observed changes in forest productivity and species distribution. In simulation models uncertainties tend to cascade onto one another; from estimating what future societies will be like and general circulation models (GCMs) at the global level, down to forest models and forest management at the local level.

Individual climate change impact studies should not be uncritically used for decision-making without reflection on possible shortcomings in system understanding, model accuracy and other assumptions made. It is important for decision makers in forest management to realise that they have to take long-lasting management decisions while uncertainty about climate change impacts are still large. We discuss how to communicate about uncertainty e which is imperative for decision making e without diluting the overall message. Considering the range of possible trends and uncertainties in adaptive forest management requires expert knowledge and enhanced efforts for providing science-based decision support.
\end{abstract}




\section{Introduction}

More than twenty years of climate change impact research have improved our understanding of the climate system (Krupa and Kickert, 1989; Solomon et al., 2007; Rummukainen, 2012) and its impact on ecosystems. While a new set of climate change projections have been made available for the Fifth IPCC Assessment Report (van Vuuren et al., 2011), most impact assessments are still based on the previous generation of climate change projections of the Fourth IPCC Assessment Report (Christensen et al., 2007). These scenarios have now been around for several years, however a knowledge and communication gap still remains as to how these climate change scenarios can be interpreted and what they imply for European forestry.

The knowledge about potential climate change impacts on European forests is continuously expanding (Lindner et al., 2010; Campioli et al., 2012; Hlásny et al., 2012; Spathelf et al., 2014) and some changes in growth (Piao et al., 2011; Sánchez-Salguero et al., 2012), drought-induced mortality (Allen et al., 2010), and species distribution (Delzon et al., 2013) have already been observed. However, it is still challenging to advise forest decision makers on planning for climate change impacts (Ogden and Innes, 2009; Peterson et al., 2011). Many uncertainties and unknowns remain (Millar et al., 2007; Yousefpour et al., 2012) and it is difficult to communicate these to practitioners and other decision makers while retaining emphasis on the importance of planning for adaptation (Spittlehouse and Stewart, 2003).

Because of resource and time limitations, many climate change impact studies focus only on a small selection of climate change scenarios instead of providing a full suite of possible futures, and the chosen scenarios often vary between alternative impact assessments. Practitioners and other decision makers often lack the expertise to understand why different studies yield differing and sometimes conflicting results. Observations of adverse climate change impacts have been increasingly reported over recent years (e.g. Sánchez-Salguero et al., 2012; Rigling et al., 2013; Ruffault et al., 2013). In contrast, the majority of published model simulations of climate change impacts indicate increasing productivity and larger carbon stocks compared to the baseline climate (Reyer, 2013). There could be several explanations for such deviations between observations and simulations. For example, the environmental conditions at the sites with adverse observed climate change impacts could differ from those where the models have been applied. Another possible explanation could be that the critical factors leading to the observed impacts, especially when extreme events are involved, are not well represented by the simulation models. Identifying the reasons for the deviations between model results and observed growth responses to climate change is crucial, as we often rely on model projections to explore future climate change impacts. Communicating the uncertainty around climate change impacts without diluting the message is a difficult task. There are many sources of uncertainty including those originating from future climate, from the sensitivity and response of forests, from simulation models, and from non-climate factors such as invasive exotic species or pests influencing climate change impacts (Reyer, 2013; Fischer et al., 2013).

The objective of this paper is to analyze and synthesize scientific knowledge as a basis of offering decision support to practitioners and decision makers in forest management. Regional climate projections for Europe are discussed and recently observed changes in mean climate variables as well as in climate extremes are described. Observed and projected climate change impacts on European forests are summarized and a description of the inherent uncertainty in climate change impact modelling is presented. The interpretation and communication of state of the art knowledge to non-scientific audiences is also discussed. This work should assist decision makers and practitioners in interpreting and responding to observed and projected climate change, its impacts on forestry and its implicit uncertainties.

\section{Regional climate change projections - mean trends and extremes}

Several limitations apply when using climate models to understand the likely effects on forest ecosystems. First, general circulation models (GCMs) project future climate for very large pixels, which are far too big to make a meaningful statement about the local climate relevant to single forest stands or local management decisions (Flint and Flint, 2012). Downscaling is necessary, but adds inherent uncertainty to the values obtained from such scaling exercises (Fowler et al., 2007). Second, forests do not respond linearly to changes in climate parameters such as annual temperature and precipitation (Stephenson, 1990), which are often used when communicating climate scenario results to decision makers. Third, climate model results vary much more at regional compared to the continental and global level. Average ensemble climate data should not be interpreted as the most likely scenario at the regional level because in reality, climate change will not happen uniformly across the continent. Depending on the (unpredictable) future location of atmospheric circulation patterns there will be regions with lower and higher temperature and precipitation changes. Therefore, using mean trends in these two variables from many models, before translating them into meaningful predictors, does not allow one to fully understand the range of likely impacts. Ensemble mean climate data always extenuate the possible regional climate change. Rather, one has to downscale all models individually, for all climate variables, generate physiologically meaningful variables thereof for each model output, and only summarize in the form of ensembles the forest response to climate change. This is a very time consuming task, yet necessary to see the full picture of likely responses. Fourth, forests only partly respond to changes in climate means. Many responses are to extremes rather than to means (Reyer et al., 2013b), and therefore, larger uncertainties in the projections of climate extremes cause considerable uncertainties when assessing the likely response of forest ecosystems towards the end of the current century. Finally, every species, and every life stage of each species responds differently to changing climate variability. While all will respond to some extent to a general increase in temperature and a regional increase or decrease in precipitation, the climate seasonality with its seasonal shifts in extremes will very differently affect the

Table 1

Mean climate trends for the period 2051-2080 for European regions from six RCMs compared to the period 1951-2000 (see Supplementary material, Table S.1).

\begin{tabular}{|c|c|c|c|}
\hline & Northern Europe & Central Europe & $\begin{array}{l}\text { Southern } \\
\text { Europe }\end{array}$ \\
\hline $\begin{array}{l}\text { Summer } \\
\text { temperatures }\end{array}$ & $\begin{array}{l}+1.5-2.6^{\circ} \mathrm{C} \\
\text { higher in } \mathrm{NE}\end{array}$ & $\begin{array}{l}+1.3-2.7^{\circ} \mathrm{C} \\
\text { higher towards } \\
\mathrm{S} \text { and } \mathrm{E}\end{array}$ & $\begin{array}{l}+2.6-4.1^{\circ} \mathrm{C} \\
\text { higher away } \\
\text { from coasts }\end{array}$ \\
\hline $\begin{array}{l}\text { Winter } \\
\text { temperatures }\end{array}$ & $\begin{array}{l}+2.5-4.2^{\circ} \mathrm{C} \\
\text { higher in NE}\end{array}$ & $\begin{array}{l}+1.5-3.5^{\circ} \mathrm{C} \text { higher } \\
\text { in } \mathrm{E} \text { and mountains }\end{array}$ & $\begin{array}{l}+2.0-2.8^{\circ} \mathrm{C} \\
\text { consistently } \\
\text { all over }\end{array}$ \\
\hline $\begin{array}{l}\text { Summer } \\
\text { precipitation }\end{array}$ & $\begin{array}{l}+0-25 \% \text { increase } \\
\text { higher in NE }\end{array}$ & $\begin{array}{l}-0-25 \% \text { reduction } \\
\text { higher in } \mathrm{W} \text { and } \mathrm{S}\end{array}$ & $\begin{array}{l}-25-50 \% \\
\text { reduction } \\
\text { higher in } S\end{array}$ \\
\hline $\begin{array}{l}\text { Winter } \\
\text { precipitation }\end{array}$ & $\begin{array}{l}+5-40 \% \text { higher in } \\
\mathrm{N} \text { and mountains }\end{array}$ & $\begin{array}{l}-10-+15 \% \\
\text { reduction } \\
\text { in } W \text { and } S\end{array}$ & $\begin{array}{l}-35-+15 \% \\
\text { reduction } \\
\text { in } S \text { and } W\end{array}$ \\
\hline
\end{tabular}




\section{Absolute Change in Moisture Index (Precipitation-PET) (mm/yr)}

Change (mm/yr)
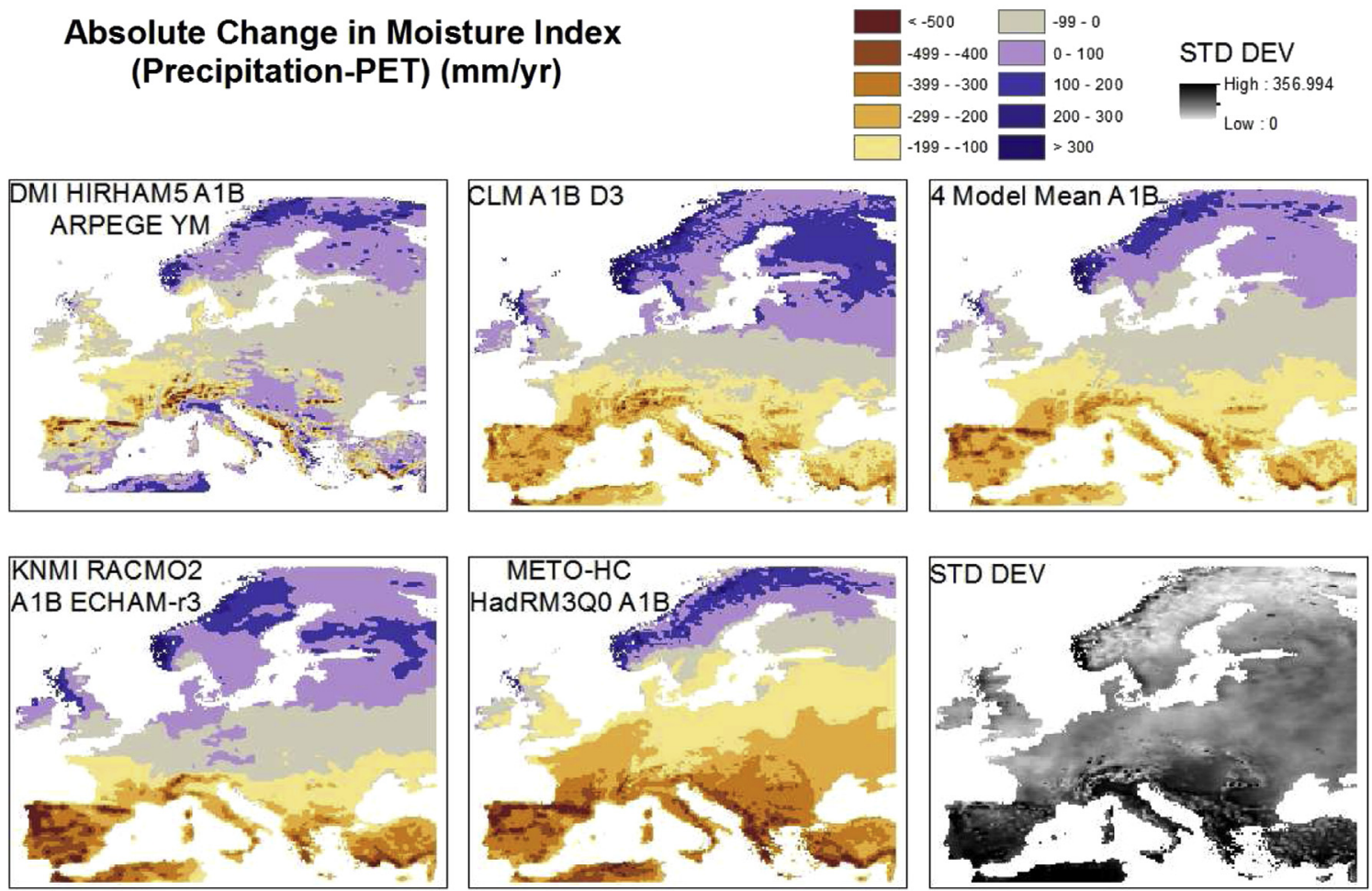

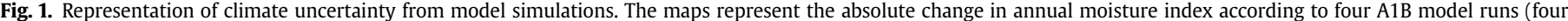

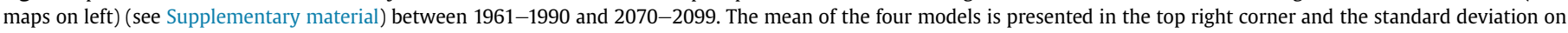

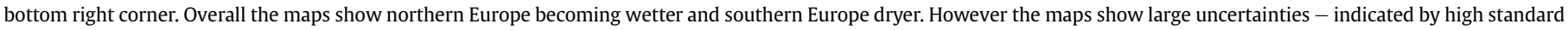
deviations - in the Mediterranean region and Southeast Europe, where much larger changes could occur than are represented by the mean ensemble trend among models.

many species that combine to make forest ecosystems (Urli et al., 2013; Dantec et al., 2014). Using simple scenarios with few climate variables as input to impact studies therefore pose limitations in capturing the full picture of likely changes which we may expect to see in the future from climate change.

Current trends in projecting future climate are usually given in the form of summary statistics that are derived from ensemble climate projections, which combine the output from many climate models. Such summaries are usually provided in periodic reports by the Intergovernmental Panel on Climate Change (IPCC) or by national authorities that extract such information from international efforts to summarize the future state at a country level. In order to provide regional or country-level information, the output from regional climate models (RCMs) is often preferred over GCMs due to the better representation of the regional topography and its influence on climate trajectories and patterns in these models. Table 1 provides a summary for three European regions based on six different RCM runs that were generated from the projections for IPCC AR4. The more recent scenarios for the IPCC AR5 span a wider range of possible climate changes compared to IPCC AR4 scenarios, but with similar average warming trends (see Rogelj et al., 2012). However, it is important to stress that the latest carbon dioxide emissions continue to track the high end of emission scenarios and fast and rigorous emission reduction efforts would be needed to meet the political target of maximum $2^{\circ}$ warming above the preindustrial level by 2100 . The current emission trajectory is in line with climate change projections of $3.5-6.2{ }^{\circ} \mathrm{C}$ increase in global mean annual temperature compared with pre-industrial levels (Peters et al., 2013), and consequently it is possible that the climate change projections presented in this paper could be considerably exceeded.

\subsection{Trends in biologically meaningful climate parameters}

Globally, the period of $2001-2010$ was $0.477{ }^{\circ} \mathrm{C}$ above the 1961-1990 mean annual temperature and was $0.217{ }^{\circ} \mathrm{C}$ warmer than the 1991-2000 decade (Morice et al., 2012). The average temperature for the European land area for the last decade (2002-2011) was $1.3{ }^{\circ} \mathrm{C}$ above the pre-industrial level, which makes it the warmest decade on record (EEA, 2012). While climatologists often present annual mean trends in temperature and precipitation, ecologists and environmental managers are interested in using ecologically and physiologically more meaningful climate parameters. Admittedly, these are also largely influenced by changes in temperature and precipitation, but the respective influence of these two variables on the outcome of certain derived variables is not linear. Therefore, it is worthwhile discussing some derived climate variables that are important for forestry. More climate variables and descriptions of how they were derived are available in the Supplementary material. Fig. 1 illustrates the differing regional patterns generated by four different RCMs under the A1B emissions scenario. Here we present the expected mean changes for the moisture index, which is the difference between annual precipitation and potential evapotranspiration (where this latter variable was derived with the 1963 formula using temperature and potential global radiation (Turc, 1963)). The average trend shows a reduction in moisture index throughout Europe, except for the most northern areas. This figure also illustrates the importance of looking at several model runs as much larger changes can regionally be expected than those indicated by the mean; resulting in high uncertainties in certain regions (lower right panel).

Fig. 2 illustrates the change in average annual maximum continuous dry days (CDD) and indicates an aggravation of the 
strong segregation between Northern Europe (currently with very short drought stretches) and Southern Europe (currently with extended drought stretches). According to these models, Central Europe will see a strong increase in the length of the average longest annual drought period by 3-15 days, now approaching numbers formerly typical for the subMediterranean belt. At the same time, Northern Europe is expected to see an average reduction in drought risks, which originates from the projected increase in rainfall for both summer and winter seasons. Depending on which single model is used, this segregation can even be stronger, since we only present a mean trend here. However, these results have to be interpreted with great caution because they refer to the average duration of the longest annual drought. For drought extremes please see Section 2.2 .

The average number of annual frost days is projected to be reduced all over Europe (see Supplementary material), but while the frequency of cold extremes is projected to decrease, there are some indications that the intensity and duration of cold extremes might persist or increase under climate change (Rummukainen, 2012). In other words, the reduced trend in average number of frost days might coincide with more frequent exceptional cold events (see Section 2.3).

The projections for average and extreme wind speeds are unclear. There is no general trend visible in the analysed models regarding changes in average wind speed. While globally it is expected that overall storm frequency may decline under climate change (Ulbrich et al., 2009), there is some indication that the frequency of the more intensive categories of tropical storms is increasing and that regional shifts in storm severity and frequency may occur (Rummukainen, 2012). For example, Pryor et al. (2012) found 10-15\% higher wind energy density for the Baltic Sea region. An increase in the top wind speed of storms was projected for Europe also by Leckebusch et al. (2008). As a consequence of longer storm paths, future storms might penetrate further into Eastern Europe (Fink et al., 2009). Still, projections of future wind climates are highly uncertain due to high stochasticity of storm events, decadal fluctuations, and also to the fact that storms are small relative to the grid sizes used in GCMs (Rummukainen, 2012). A recent study with a very highresolution climate model indicated that the occurrence of hurricane-force storms over Western Europe during early autumn could increase significantly, because tropical cyclones could more frequently follow pathways directly to Europe (Haarsma et al., 2013).

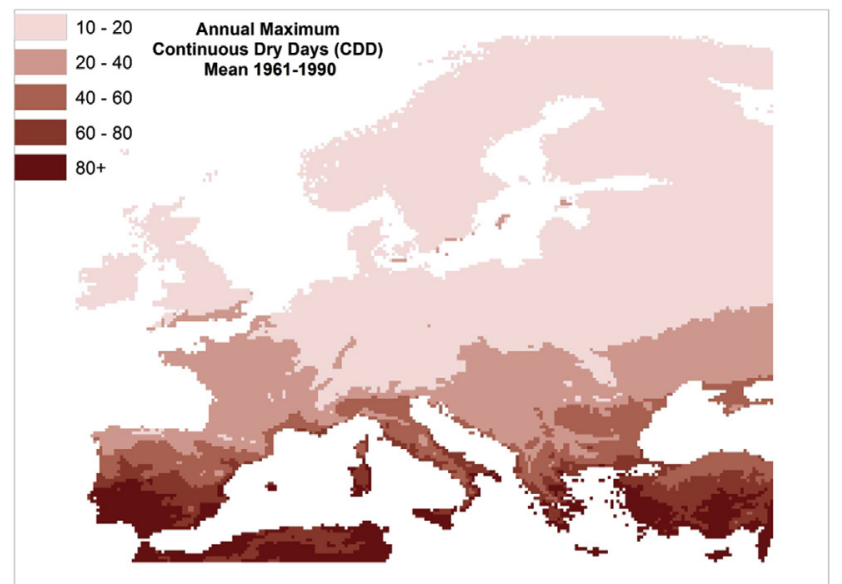

\subsection{Observed changes in climate extremes}

The IPCC report on extreme events analysed the evidence of already observed changes of extreme events since 1950 (Field et al., 2012). Recently the World Meteorological Organisation has published a report on climate extremes in the decade 2001-2010 (WMO, 2013). Two extreme heat events occurred in Europe in 2003 and 2010. The hot summer of 2010 was a so-called Mega-heat wave with a heat record in Moscow and serious wild fires affecting more than 1 million ha of land area (Barriopedro et al., 2011). Much of Western Europe was affected by a severe drought in 2003 and central European Russia experienced a drought in 2002, which saw record low rainfalls over a 5 month period. There has also been an observed increase in severe cold waves in the Northern Hemisphere in recent years. Notable examples are the severe winter of 2009/2010 and the cold temperatures of March 2013 in Europe. Rummukainen (2012) summarised that there is also evidence for a regional increase in frequency of precipitation related extremes (i.e. heavy precipitation, drought conditions). Observed changes in precipitation were less robust due to larger spatial and temporal variability. The trends concerning increased heavy precipitation events were most consistent over central Western Europe and European Russia.

\subsection{Changes in occurrence of climate extremes}

In general, we can expect that both temperature and precipitation extremes will increase (Seneviratne et al., 2012). However while the mean climate trends are still uncertain, it is even more difficult to project changes in climate extremes. The confidence in projections of extreme events depends inter alia on the limitation of global and regional climate models related to the spatial resolution and the representation of physical climate processes (Rummukainen, 2012) as well as on the assumed emission scenarios. It is evident that extreme events have the potential to affect forests much more than gradual changes in temperature. According to results of a variety of GCM and RCM runs and emission scenarios (Field et al., 2012; Solomon et al., 2007) there is a high confidence in an increase of warm days, primarily in summer and in Southern and Central Europe. Fischer and Schär (2010) found that European summer heat waves would become more frequent at the end of the century and other characteristics of heat waves like duration and amplitude (intensity) would change regionally. Coumou and Robinson (2013) found that multiple climate model runs predict a robust several-fold

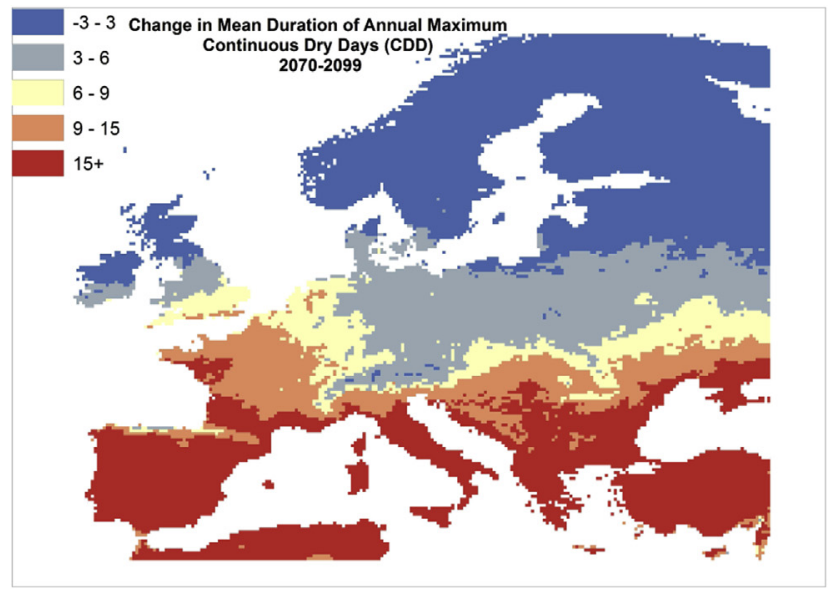

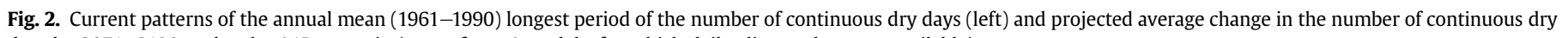
days by 2071-2100 under the A1B scenario (mean from 4 models, for which daily climate data was available). 
increase in the frequency of heat extremes irrespective of emission scenario by 2040. Field et al. (2012) reported an overall increase in heavy precipitation days all over Europe; this trend is strong in Northern Europe particularly in winter. An increase in heavy precipitation intensity could be possible despite decreases in summer precipitation means in some regions like Central Europe. Rummukainen (2012) concluded that the projected increases in extreme precipitation in winter for Europe are rather robust. Drought risk, e.g. indicated by the index of continuous dry days (CDD), which is strongly related to seasonal precipitation, mainly will intensify in Mediterranean Europe (Field et al., 2012) but also extends to Central Europe (Fig. 2). Changes in the duration of the most extreme drought period indicate that these get much longer across all of Europe. Even in the north, where the average maximum CDD length declines, models project that the most extreme drought events would become much longer in 2070-2099 compared to 1961-1990. For example, the thirty year maximum length in CDD in Eastern Finland may increase from 27 to 39 days (average of four models). For a region in The Netherlands, the respective increase could be even more severe from 29 to 55 days. These results suggest that the variability between years might become a more important consideration for the management of forests, because even in a future that is on average wetter, it is likely that extreme dry years will occur more frequently. Similar results were found by an analysis of soil moisture changes indicating enhanced drought on the annual time scale in the Mediterranean and parts of Central Europe (Orlowsky and Seneviratne, 2012).

\section{Projected and observed impacts of climate change on forests}

It is imperative for impact studies to explore the full breadth of variation and uncertainty from climate studies on biological responses, instead of simply exploring the effect of the mean of projected trends. The range of possible impacts can only be understood if done in such an ensemble mode. To provide an overview of the potential impacts, the main trends reported by studies are discussed addressing (i) growth/productivity changes, (ii) species suitability changes, and (iii) disturbance trends, with some focus on recent European-scale analyses.

\subsection{Observed impacts}

\subsubsection{Growth and productivity}

Over the twentieth century, trends in forest productivity were generally positive, except for sites where low water availability, low air temperature and (or) low nitrogen deposition levels limited growth, i.e., in Mediterranean or boreal regions (Boisvenue and Running, 2006; Kahle et al., 2008; Spiecker et al., 1996). More recently, however, there are an increasing number of studies pointing to adverse effects of climatic changes on growth and vitality of trees (e.g., Bigler et al., 2006; Piao et al., 2011; Sarris et al., 2011; Vicente-Serrano et al., 2010). Especially for European beech (Fagus sylvatica L.), there is increased evidence for drought-induced growth decreases throughout the distribution area of the species (Kint et al., 2012). In north-eastern France for example, Bontemps et al. $(2009,2010)$ observed a decline in dominant radial and height growth of beech in the 1990s, which was confirmed by Charru et al. (2010). This latter study, based on French national forest inventory data, showed a drop in basal area increment of 5\% over the period 1987-2004 in response to severe drought events. Also in low-mountainous areas in Spain, beech decline was observed and linked to recent warming (Jump et al., 2006; Penuelas and Boada, 2003).

\subsubsection{Tree species movements}

Most species studied have tracked recent warming only partly or not at all (Zhu et al., 2012; Allen and Breshears, 1998; Lenoir et al., 2008) highlighting recent migration lags. Altitudinal and latitudinal shifts in tree species distributions have been reported for the Montseny Mountains, where beech is replaced by Holm oak (Quercus ilex L.) (Penuelas and Boada, 2003). Migration rates are primarily observed as a slow migration into newly suitable habitats at the leading edge of a species range due to a relaxation of cold temperature constraints. Examples for such range adjustments include the upper tree line with upwards shifts of forest woody species (Lenoir et al., 2008) and temperate and sub-Mediterranean tree species (Urli et al., 2014). Massive colonization of Holm oak occurred in all the forests studied along the Atlantic coast; the species started to colonize new areas in the early 1900's and spread considerably during the middle of the century. Most inventories are now indicating the presence of Holm oak over the whole area of all investigated forests in Western France. However, the maximum rate of colonisation by this species was much slower than that necessary to follow changes in climate-related habitat suitability since the early 1900 's. It is now likely that tree species won't be able to track climate change at the speed of climate change due to a lack of dispersion ability (Delzon et al., 2013). At the rear-edge of tree populations, a comparably rapid response compared to the leading edge can be observed already, be it directly due to drought (Adams et al., 2009; Anderegg et al., 2013; van Mantgem et al., 2009; Allen et al., 2010), or due to secondary damage by forest insects and pathogens (Jactel et al., 2012). In the lowest altitudes of the Valais, Switzerland, which also represents the rear edge of the species, a significant dieback in Pinus sylvestris with a lack of natural regeneration has been observed over the past $10-15$ years (Rigling et al., 2013). A recent study showed that all forest biomes were equally vulnerable to drought regardless of their current rainfall environment (Choat et al., 2012), explaining why drought-induced forest decline is currently occurring not only in arid regions but also in wet temperate forests not normally considered at drought risk.

\subsubsection{Disturbances}

In general, it is difficult to label individual disturbance events as being caused by a changing climate. Instead, climate change effects will become apparent through increased frequency of events, or by unprecedented magnitude of events. For example in Switzerland it has been shown that measured wind gust speeds have increased strongly since the beginning of records in 1933 (Usbeck et al., 2010b). However, especially with stochastic events such as storms, it takes a long time before trends can be distinguished from natural fluctuations. Another confounding factor is that impacts of disturbances are also influenced by the state of the forest, which changes over time as well. Seidl et al. (2011a,b) found that about half of the observed increase in disturbance impact in Europe's forests over the period 1958-2002 (for fires, storm and bark beetles) could be attributed to changes in the state of the forest, while the other half was attributed to climate change. Similarly, Moraal and Jagers op Akkerhuis (2011) found insect pest occurrence in the Netherlands since 1946 to be influenced by changes in forest composition, but also found climate change impacts such as invasion of more southern species and changes in winter survival rates. The storm Kyrill of January 2007, penetrated far into Europe and affected an exceptionally large land area (Fink et al., 2009). Exceptionally large forest fires during the last decade have been associated with extreme weather conditions that exceeded the normal range of climate variability as demonstrated e.g. for the 2010 fire season in Russia (Barriopedro et al., 2011; Rahmstorf and Coumou, 2011), but also the 2003 and 2005 fires in Portugal and the 2007 fires in Greece were characterized by extremely long dry 
spells with hot temperatures and high wind speeds (San-MiguelAyanz et al., 2013; Koutsias et al., 2012).

\subsection{Projected impacts}

\subsubsection{Growth/productivity}

Reyer et al. (2013a) have recently applied a process-based forest model to study the impacts of climate change on net primary productivity (NPP), using a network of ICP forest plots across Europe. Fig. 3 shows the model results compared to data from a literature review of similar modelling studies (Reyer, 2013). Projected impacts differ clearly between impact studies that do or do not consider the effect of increasing $\mathrm{CO}_{2}$ contents in the atmosphere. While it is proven that atmospheric $\mathrm{CO}_{2}$ contents are increasing significantly, it is still unclear, to what degree $\mathrm{CO}_{2}$ fertilization affects forest growth and productivity in natural and managed ecosystems over longer periods of time. Recent model evaluations against experimental data from free air $\mathrm{CO}_{2}$ enrichment (FACE) experiments have shown that terrestrial carbon cycle models generally overestimate the response of gross primary productivity (GPP) to $\mathrm{CO}_{2}$ fertilization (Piao et al., 2013). A crucial question in this context is how much the water use efficiency of trees may benefit from the enhanced $\mathrm{CO}_{2}$ concentration, because higher water use efficiency could at least partly counteract increasing water shortages under climate change (Battipaglia et al., 2013; De Kauwe et al., 2013; Keenan et al., 2013). Because of the high model uncertainties related to $\mathrm{CO}_{2}$ fertilization, it seems advisable that alternative model runs with and without increased $\mathrm{CO}_{2}$ fertilization effects are compared to identify the $\mathrm{CO}_{2}$ related uncertainties in the simulated climate change impacts. Such model experiments can approximate the effects of $\mathrm{CO}_{2}$ with persistent $\mathrm{CO}_{2}$ fertilization effects or alternatively with a levelling-off of $\mathrm{CO}_{2}$-effects when plant photosynthesis is acclimatizing to higher $\mathrm{CO}_{2}-$ levels or limited by other factors. The effect of these two assumptions is shown in Fig. 4 for an application of the $4 \mathrm{C}$ model across Europe (Reyer et al., 2013a). The model results underline the huge influence that one single factor $-\mathrm{CO}_{2}$ fertilization - has on the projected climate change impacts with this particular model: In six out of ten environmental zones, climate change without increasing $\mathrm{CO}_{2}$ concentrations had a positive long term effect (2061-2090) on average across multiple sites. The increase in these regions was much higher with the additional consideration of $\mathrm{CO}_{2}$-effects (around $+15 \%$ higher NPP increase). The four environmental zones with on average negative climate change impacts without $\mathrm{CO}_{2}{ }^{-}$ fertilization showed also much higher NPP with $\mathrm{CO}_{2}$-effects.

In a similar modelling study as the one by Reyer et al. (2013a) but now for all biomes of Europe in a $0.5^{\circ}$ Lat/Lon grid using LPJWSL (Poulter et al., 2011), very similar results were obtained. Large regions in Southern Europe and - depending on the scenarios used - even further north in Central Europe showed mainly negative growth responses to climate change if atmospheric $\mathrm{CO}_{2}$ concentration was kept stable at current levels. It was only in Northern Europe that NPP was simulated to increase towards the end of the century. However, if $\mathrm{CO}_{2}$ was simulated to increase as projected in the different climate change scenarios, then only very small regions in Southern Europe revealed negative trends in NPP, while most regions showed an increase in NPP by the end of the century, compared to current climate and $\mathrm{CO}_{2}$ concentrations. It should be noted that the uncertainty among climate models used for these NPP effects was considerable.

\subsubsection{Changes in species suitability}

Using climate data from the A1B scenario for six RCMs and species data from the ICP Forest Level I data set (Fischer et al., 2010), the expected change in species' habitat suitability in response to climate change was simulated for a range of tree species by calibrating six different statistical models (Zimmermann et al., 2011; see Supplementary material (S6) for details on the methods and data used). These so-called species distribution models (SDMs; for an introduction, see Guisan and Zimmermann, 2000) allow for mapping a species' habitat suitability as a function of climate and topography, and represent a rapid method to assess potential impacts of climate change on the spatial suitability patterns of individual tree species (e.g. Meier et al., 2012). Several SDMs and climate models were combined in an ensemble projection (Araujo and New, 2007) in order to account for projection uncertainties
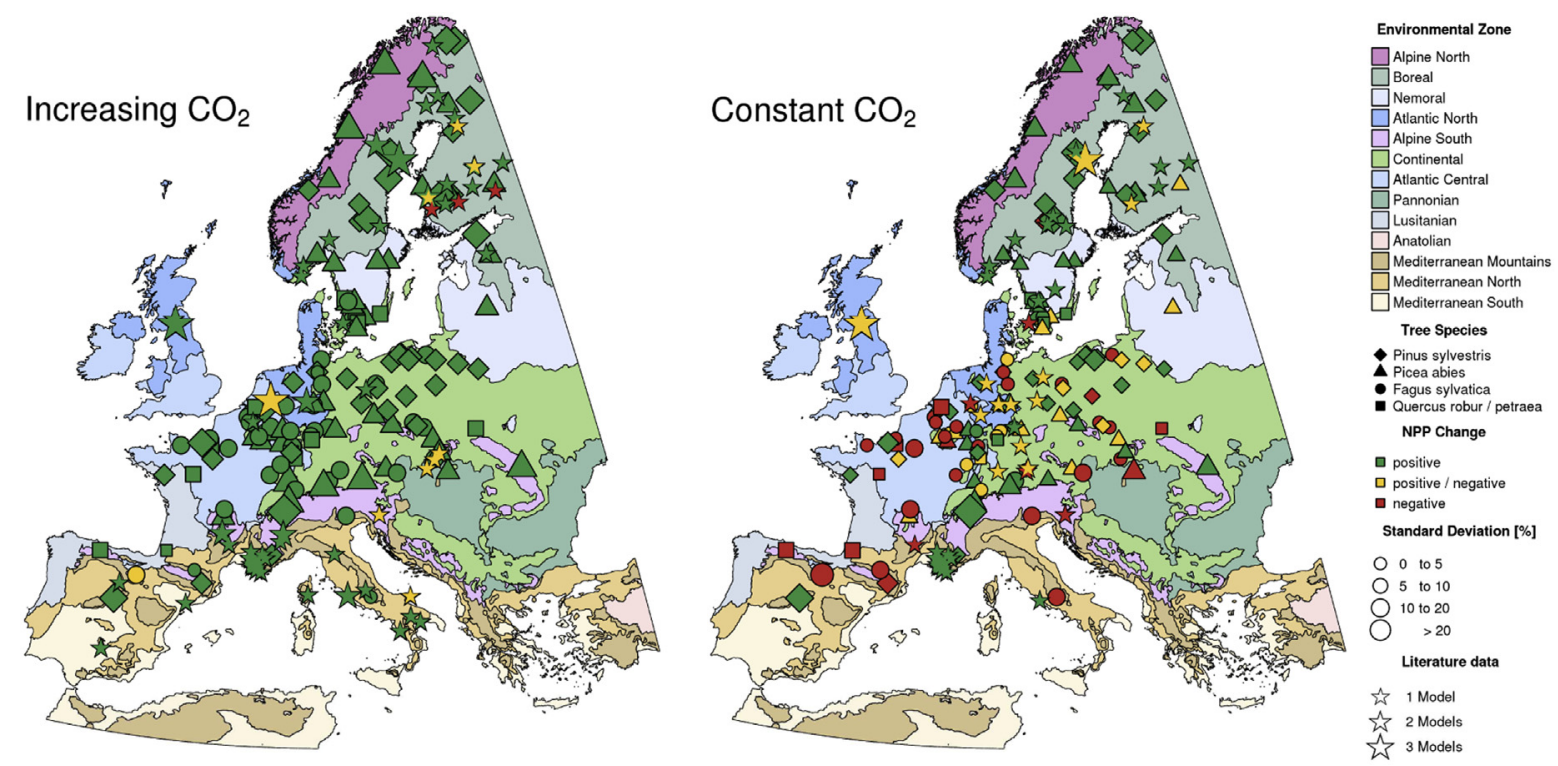

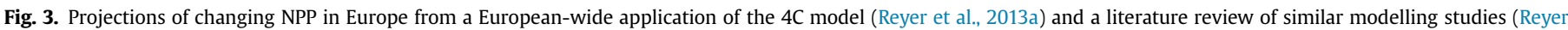

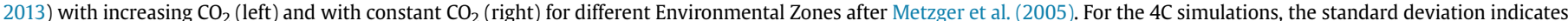

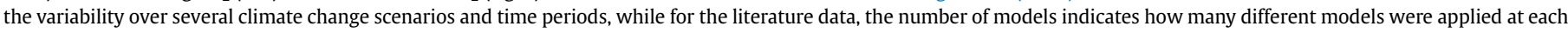
site. 


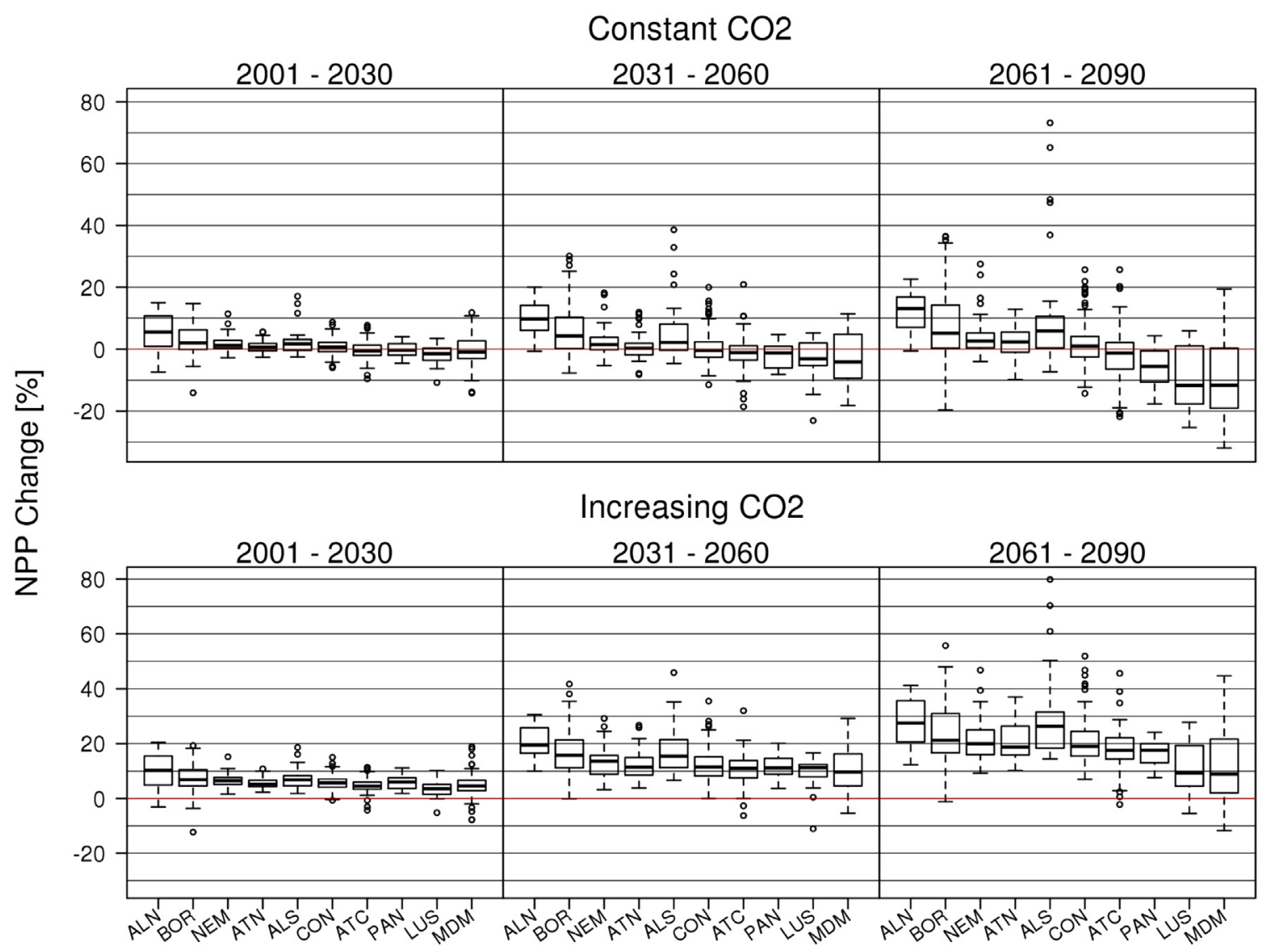

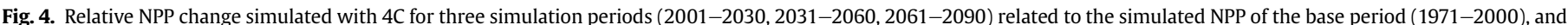

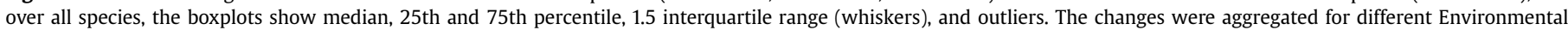

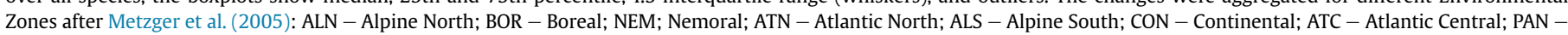
Pannonian; LUS - Lusitanian; MDM - Mediterranean Mountains (for more information see Reyer et al. (2013a).

arising from the choice of statistical and climate model (Buisson et al., 2010). By 2100, significant changes in tree species suitability patterns can be expected as illustrated in Fig. 5, indicating considerable shifts in functional groups of trees and whole biomes, mapped here simply as a consequence of changing climates, but uncorrected for realistic migration rates (Zimmermann et al., 2011).

Projected tree species responses generally illustrated the tendency to shift their ranges to more Northern latitudes or

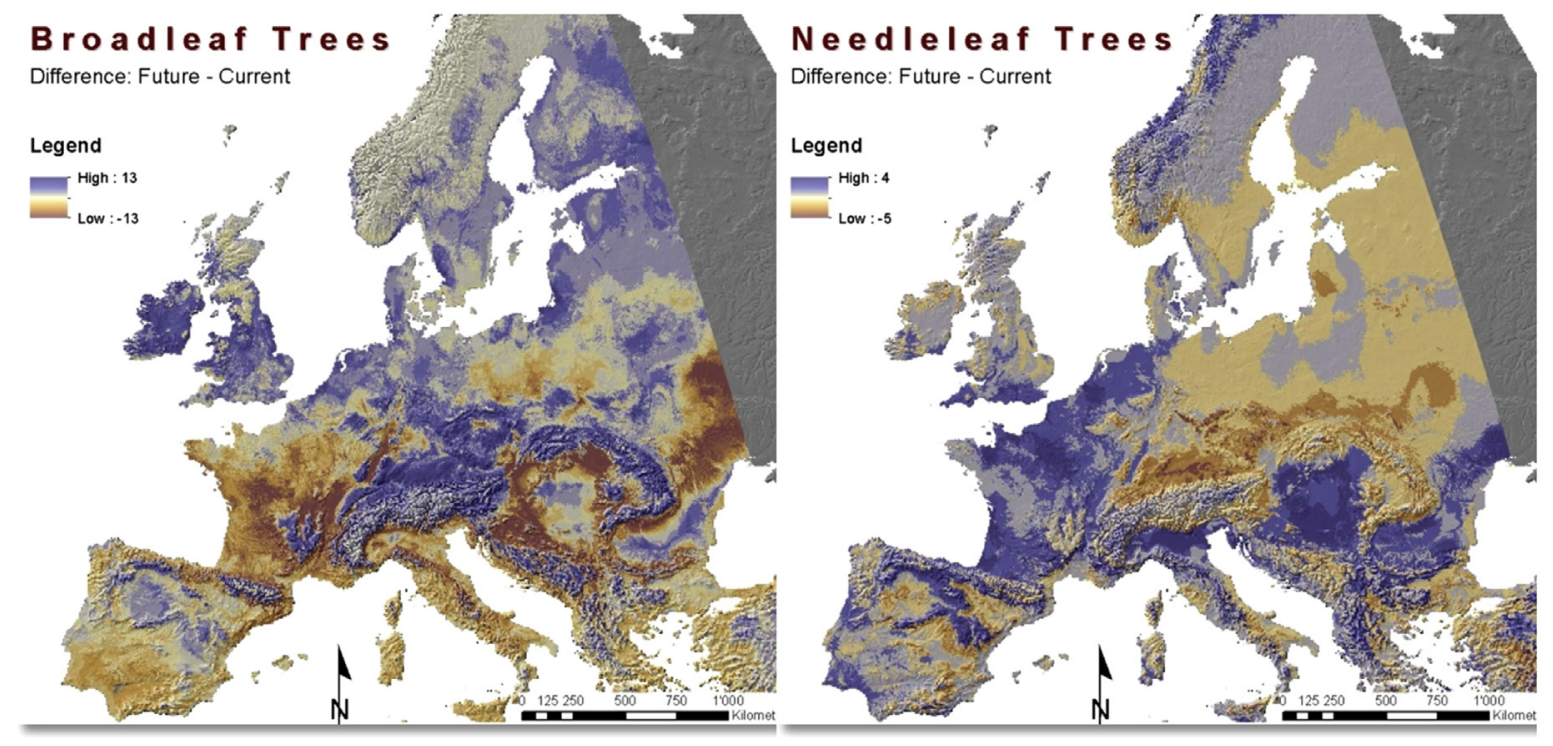

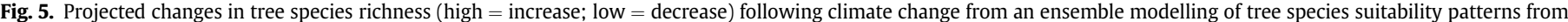

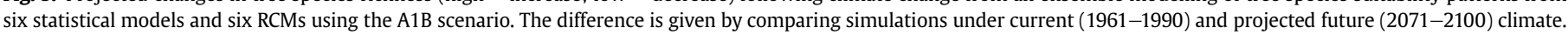


higher altitudes by the end of the Century. Hanewinkel et al. (2013) studied associated gains (North) and losses (Central and Southern Europe) in forest economic value based on such projected decreases of the potential range of mesic, cold - adapted species like Norway spruce, and increases of drought - adapted species like Mediterranean oaks in order to understand how range shifts may affect timber production of European forests and consequently downstream timber industries. However, it is important to stress that species distribution models presented here do not represent forecasts of what will most likely happen by 2100 . Rather, the models illustrate how much the habitat suitability of a given species is likely to change by 2100 , without indicating how fast the trees actually will respond. Although some species are moving already, their ability to track climate change is still unclear. Some of the early successional species, such as birch (Betula pendula) or poplar (Populus tremula) might respond with little time lag, while late successional species (Quercus) might show considerable time lags in adjusting their ranges due to very slow migration rates (Meier et al., 2012; Delzon et al., 2013). Equally important is the question to what extent and at what rate species will decline at the rear edge of their distribution, when environmental conditions become less suitable or completely unsuitable. The modelling of the realised niche of species often overestimates range declines as the current range limits are not always constrained by climate. In other words the physiological limits of species are usually wider than the boundaries of the current distribution range (e.g. Loehle and LeBlanc, 1996; Kearney and Porter, 2009).

Another difficulty associated with these projections is that trees might not only respond to shifting mean climate values, but instead - or in addition - to changes in extremes (see Section 2.3). Indeed, an earlier study demonstrated that adding measures of climatic extremes to SDMs improved model projections (Zimmermann et al., 2009). Yet, the improved models still do not include a mechanistic response to extremes and are not capable in projecting how fast trees will adjust their ranges to changing climates. This is due to a lack of included mechanisms of disturbance, mortality and regeneration.

Moreover, forest management in Europe has a long history of planting coniferous species outside of their natural ranges. Despite their higher sensitivity to some disturbance agents, these species are often preferred by forest managers as they offer higher economic value compared to ecologically more suitable species (Knoke et al., 2005). It can be anticipated that managers will continue to choose species according to other factors as well as habitat suitability and this will likely result in quite different realised range shifts in the future.

\subsubsection{Disturbances}

The impact of disturbances on forests is affected by both driving weather variables and the state of the forest (Seidl et al., 2011a,b). Here we focus only on the weather component and how projected climate change might influence future disturbance impacts.

Fire risk is clearly related to warm, dry and windy conditions. Several indices have been developed to summarise relevant weather variables into one figure (Holsten et al., 2013). In Europe, the most commonly used index is the Canadian Fire Weather Index (Van Wagner, 1987). Such indices can be applied to projected climate data in order to obtain an impression of how severely the future fire weather would change. Such studies invariably show increasing levels of fire danger, such as in France (Chatry et al., 2010), Portugal (Carvalho et al., 2011) and the Mediterranean basin as a whole (Moriondo et al., 2006). The rest of Europe has been studied less intensively, but also other regions are likely to face increased fire risk (Lavalle et al., 2009).
Climate change will also affect the risks of insect pest outbreaks both directly through effects on population growth and survival rates, but also indirectly by affecting the vitality of the trees. Because insects are poikilothermic organisms, global warming is expected to enhance their winter survival and development rate thus triggering increases in population abundance and risk of outbreaks (Robinet and Roques, 2010). Furthermore, damage by secondary pests such as bark beetles is likely to increase with water stress severity (Jactel et al., 2012) following decreases in summer precipitation and increased temperatures as predicted in Europe by climate models (Klapwijk et al., 2011). How pathogens will react to climate change is not very well understood. However, there is also evidence of increased pathogen attack in trees after drought (Desprez-Loustau et al., 2006).

The possible increase in top wind speeds during the most intense storms could lead to higher wind damages in parts of European forests (Gardiner et al., 2012). Climate change may also affect the resistance of trees to uprooting. Wetter and warmer winters are likely to increase wind damage because of poorer rooting (Usbeck et al., 2010a). Such weather patterns may also weaken rooting in Northern Europe where soils are normally frozen during the winter (Peltola et al., 1999).

\subsection{Comparison of observed impacts with expectations from projections}

There is a clear discrepancy between the majority of projected climate change impacts and recent observations. Recent evidence about growth declines and species die-back stresses the importance of extreme events for triggering drastic impacts on tree growth and survival. Climate variability and extreme events are still poorly represented in most ecosystem simulation models (Reyer et al., 2013b) and that explains why the projected impacts often display a more positive situation, at least in the short- to mediumterm. For example, the exceptional drought year of 2003 showed a moisture index value that was similar to the projected average value calculated by climate models for around 2060 (Ciais et al., 2005). As most simulation studies would only "see" this degree of drought stress in the second half of the century, it is not surprising that discrepancies can be quite large. We are still lacking good understanding of how improved growth conditions in average years interspersed with a few exceptional years of adverse growth conditions will affect forest ecosystems. We can expect positive growth changes in average climatic conditions during the next few decades due to the fertilization effects of increased $\mathrm{CO}_{2}$ concentration, but also because of higher temperatures combined with sufficient precipitation in some parts of Europe. Forests will face, however, increasingly severe extreme events as well. It is these exceptional events that will drive changes in ecosystem composition (Dale et al., 2001; Ciais et al., 2005) and structure (Allen et al., 2010). This would suggest that some observed species changes following the extreme event in 2003 could be similar to equilibrium SDM responses after 50 years. Simulation results for the Valais in Southern Switzerland with a strong climate change scenario were quickly producing similar species loss as recently observed (Bigler et al., 2006). In this region, the realised niche of Scots pine is very close to the species' fundamental niche, so that the SDM projects a fast decline of the species. For other locations and/or species the difference between realised and fundamental niche and the deviation between simulated and observed changes could be larger.

On the other hand, niche modelling generally predicts substantial northward shifts in suitable habitats. The contemporary rate of range expansion of Holm oak in Western France in response to global changes is much lower than would be required to track 
future climate change according to the predictions of niche modelling and phylogeographic studies (Delzon et al., 2013). These results indicate that the speed of tree dispersion and establishment will in many cases not allow for colonising all the climatically suitable habitats that are likely to appear in Europe over the next 50 years or so.

Observed growth changes for Scots pine in Spain (Vayreda et al., 2012) were qualitatively similar to the projected productivity changes simulated for future climate. But generally there is little evidence available demonstrating how well simulated growth and productivity changes are reproduced in real forests under climate warming as observed over the last two decades. Most model validations have been made against historical growth observations. It would be very valuable to utilize observations from intensive forest monitoring plots (e.g. from the ICP forest network) and targeted experimental studies to validate forest simulation models under transient climate change conditions. Even more difficult is the comparison between simulated and observed disturbance impacts. As discussed before, it is difficult to detect the climate induced component in disturbance impacts. The same holds also for observed changes.

In south-western Germany, Norway spruce has lost about 7\% of its total area and has been replaced by deciduous species between the first and the second National Forest Inventory (1987-2002; roughly around 90,000 ha). Although a part of this can be assigned to planned management activities (i.e. active forest conversion), this process is largely driven by disturbances, mainly in the form of extreme events (storm damage followed by bark beetle outbreaks (Hanewinkel et al., 2011)). The majority of published forest impact studies do not properly account for disturbance effects and this is well recognized as a major development need for forest ecosystem modelling (Seidl et al., 2011a,b).

When discussing impacts of climate change on European forests, we have to take into account that these forests are more or less intensively managed. Management has strongly affected the present species composition in European forests (Spiecker, 2003) and it will continue to be of major importance in responding to climate change. Koehl et al. (2010) found in a simulation study that the effects of climate change on the future productivity and species composition of German forests was minor compared to the effects of forest management. Management activities such as planting of better adapted species or removing bark beetle infested trees greatly alter forest dynamics as they occur in natural forests.

\section{Uncertainties and climate change impacts on forests - what do we know and how do we communicate them?}

\subsection{Uncertainties}

Impact assessments for forests are uncertain due to several reasons. In fact, uncertainties accumulate along a 'cascade of uncertainty' (Schneider, 1983; Jones, 2000; Reyer, 2013). This cascade has two dimensions: the first relates to the modelling chain used in climate change impact assessments and the second to the different components of uncertainty at each step of the chain (Fig. 6).

A typical modelling chain for climate change impact studies is shown in Fig. 6 and can be described as follows. Since anthropogenic climate change is mostly driven by an increase in the atmospheric concentration of greenhouse gases, usually in a first step, assumptions about the development pathways of future societies have to be made. The most well-known examples of development pathways are the different storylines of the IPCC's Special Report on Emission Scenarios (SRES, Nakicenovic and Swart, 2000). These storylines are then fed into Integrated Assessment Models (IAMs), which project the greenhouse gas emissions associated with each

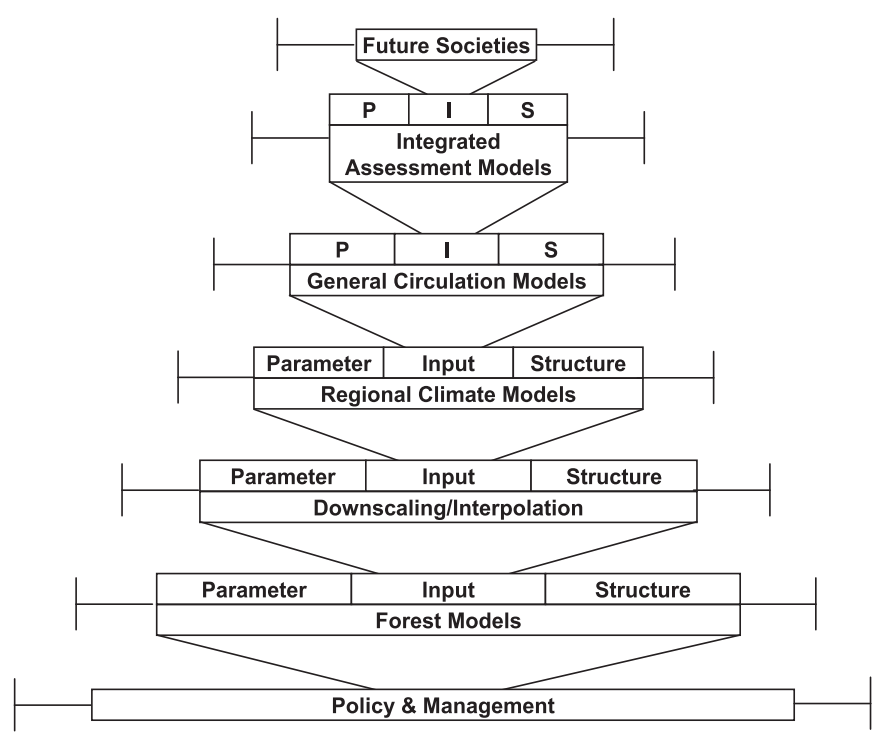

Fig. 6. The Cascade of uncertainty. The upper boxes of each compartment represent three locations of uncertainties common to every step of the cascade and the stylized error bars the range of uncertainty (Reyer, 2013).

development storyline. The newly developed RCP scenarios (Moss et al., 2010; van Vuuren et al., 2011) follow a different logic but the implications for the model chain remain similar. The projected greenhouse gas emissions then drive GCMs to provide global climate change scenarios, usually on a $2.5-0.5^{\circ}$ grid. For regional applications, the GCM results are then downscaled to lower resolutions $\left(0.5^{\circ}\right.$ and smaller) using RCMs. To use that data at the forest stand level, a further downscaling/interpolation to the points at which particular forest stands will be simulated is required. After the interpolation/downscaling, the data may be used as input into a stand-level forest model. The results of the forest model can then be fed into decision support systems or other toolboxes and models that support decision-making in forest management and policy.

At each step of the modelling chain, uncertainties in simulation models are linked with the model structure, as well as with inputs and parameters of the models (Walker et al., 2003). GCMs do not yield the same results if run twice with exactly the same input, parameters, boundary conditions etc. since they may contain stochastic elements (Le Treut et al., 2007), which is part of the structural uncertainty. Input uncertainty comes with data for initial conditions and driving variables. For example, the grid cell size of the input data influenced NPP predictions of forest ecosystem and biosphere models (Jenkins et al., 2001). Uncertainty of model parameters can also have a strong influence on the results. Projections of future carbon dioxide $\left(\mathrm{CO}_{2}\right)$ levels in a coupled climate carboncycle GCM, for example, are very sensitive to one parameter that governs the response of soil respiration to temperature (Jones and Moberg, 2003). Uncertainties related to the model parameters can be expressed by a distribution of parameter values so that a range of impact results is generated rather than a single value.

Quantifying uncertainties at specific points in the cascade of uncertainty has been subject to research for a long time. However, only rarely, the effects of model structural, input and parametric uncertainty are considered together and even less at different steps of the modelling chain (Reyer, 2013). Although this is not always possible in a systematic way because knowledge is lacking or disputed, uncertainties can still be quantified by comparing model simulations with alternative assumptions just as described earlier for considering the effects of $\mathrm{CO}_{2}$ on forest productivity. Moreover, it is important to note that all three aspects of uncertainty (model 
structure, input and parameters) at each step of the model chain contain different levels of uncertainty. There may be statistical and scenario uncertainty and uncertainty due to recognized and total ignorance (Walker et al., 2003). Statistical uncertainty refers to the measurement uncertainty, hence sampling error, inaccuracy and imprecision. Scenario uncertainty deals with plausible changes, which are based on assumptions and not (easily) verifiable. The uncertainty due to recognized ignorance relates to the "known unknowns", hence a lack of knowledge about the system which maybe reducible or irreducible. Finally, uncertainty due to total ignorance refers to the 'unknown unknowns', hence to issues we are not even aware of that we are not aware of.

\subsection{Handling uncertainties in decision support on climate change impacts on forests}

Two decades of intensive research efforts in global climate modelling have not succeeded in considerably reducing uncertainty around our future climate (Knutti and Sedlacek, 2013). Part of this uncertainty depends on the future development of GHG emissions. To limit climate warming below $+2{ }^{\circ} \mathrm{C}$ globally would require reducing $\mathrm{CO}_{2}$ emissions from the current level of almost $10 \mathrm{Pg} \mathrm{C}$ per year to less than 4 Pg C per year by 2050 (Peters et al., 2013), which is a factor 4 smaller than the 16 Pg C per year that would result from a continuously rising emission trend as assumed in the A1B scenario of the 4th IPCC report. Even a perfect global climate model could not forecast the future climate conditions under such uncertain driving forces. But we also know that global climate models are not perfect and until around 2070, the uncertainty in climate projections is dominated by the uncertainty inherent in the models themselves (Kjellström et al., 2011). The local spread between models is still large in the new RCP climate scenarios (Knutti and Sedlacek, 2013).

Mean trends from ensemble climate model projections may be robust when interpreted at the global level, but due to the large internal variability of the climate system it is crucial to compare different model projections for the assessment of climate change impacts at the regional level. Systematic comparison of impact models is less developed than the comparison of climate models. While the latter are global/regional and easier to compare, many impact studies are local and have used different models with variable assumptions.

Model projections may converge somewhat in the future with improved understanding of the climate system, but there is no reason to expect that the uncertainties around future climate development will generally disappear during the coming years or even decades. What does this mean for decision making in forest management? It is clear that uncertainties are inherent to the system we are trying to forecast and thus unavoidable. Waiting for improved evidence and information cannot be the solution. Decision makers in forest management have to realise that they must take long-lasting management decisions while uncertainty about climate change impacts are still large.

The comparison of climate change impact studies with alternative model assumptions shows how difficult it is even for experts to draw conclusions from individual impact studies. Before using the assessment results in management decisions, it is crucial to understand what assumptions were used in the impact assessment. It is specifically important to know: whether only one or multiple climate change scenarios were used; if growth responses to $\mathrm{CO}_{2}$ fertilization and disturbances (including extreme events) were considered; what niche concept (the realised or physiological niche) was the basis for modelled species ranges; and whether provenance differences, genetic adaptation or species migration were taken into account. Considering and interpreting the consequences of all assumptions is already challenging for scientists. Obviously the challenge is even larger for non-specialists.

Possible procedures to handle uncertainty such as aggregating alternative model outputs do not help a lot in this situation. While it is possible to aggregate and possibly weigh outputs of different models (e.g. by model precision or performance), this does not remove much of the underlying uncertainties in future development of important drivers, nor does it resolve our lack of understanding of crucial ecosystem response patterns (e.g. on $\mathrm{CO}_{2}$ fertilization effects). Therefore there is a risk that averaging different model outputs could suggest to the user a higher precision about future impacts, which really does not exist. What model ensemble runs can show, is the full range of uncertainties that we actually cover with our current understanding of the system.

In several studies including IPCC reports, the authors have tried to address the uncertainties in our knowledge by flagging statements with high/medium/or low confidence. This is certainly useful as a measure to provide more information to decision makers about comparative reliability of our current knowledge. When scientific evidence increases e.g. in successive IPCC reports, this gives a meaningful message to non-scientists. It should be stressed, however, that low confidence statements may be caused by larger system variability and scarce historical observations especially in context of wind disturbances and other extreme events. For example, low confidence in a particular model outcome (e.g. "devastating storms are projected to become more frequent under climate change") does not mean that there is a high likelihood for an alternative interpretation ("climate change does not affect storm damage risk").

Methods and approaches that study decision making under climate change also focus on how to consider uncertainties. How can management be adapted under climate change? Waiting 40 years to get sufficient knowledge about the realised climate change trend as demonstrated in a theoretical analysis by Yousefpour et al. (2013) is not practical to a forest manager who faces a decision making problem today. There are many strategies available on how to adapt forest management (e.g. Bolte et al., 2009; Fitzgerald and Lindner, 2013; Kolström et al., 2011). In this paper we do not intend to go into details on adaptive forest management strategies, but still we wish to draw conclusions from the analysis to identify needs for adjusting management strategies. The lack of precise projections calls for strategies that increase the resilience of forest systems - where resilience is defined as the capacity of an ecosystem to absorb disturbance and retain its function and structure (Walker and Salt, 2006). Other approaches that have been proposed include searching for no-regret strategies that yield benefits even in absence of climate change, and favouring reversible and flexible options over irreversible choices (Hallegatte, 2009) and focussing on adaptive management which is continuously reassessing itself (Seppälä et al., 2009). Moreover, management tactics including monitoring, forecasting, planning and use of mitigating strategies are essential components for managing uncertainties; e.g. those related to biotic forest disturbance risks (Sturrock et al., 2011).

It seems that projecting future forest conditions has become (and will get even more) complex. But despite these complexities, clear messages are needed to inform decision making. So where is the highest congruity in the multitude of outcomes of climatechange related impact studies on forests?

- Despite considerable variation und uncertainty in ensemble models, some general trends are common to all existing climate scenarios such as warmer temperatures, increasing moisture limitations and enhanced extremes. 
- Climate observations suggest that the last 20 years were on the higher end of the existing SRES scenario range. New IPCC AR5 scenarios include stronger warming scenarios, but these have not yet been used in impact assessments. The existing range of impact studies does therefore not cover the most extreme climate change conditions.

- Extreme events such as the drought of 2003 are not yet included in many current impact studies, but these will affect ecosystems more drastically than average climate conditions.

- Changes in the temporal distribution of precipitation are likely to have larger effects on forests than temperature changes, but they can be regionally more variable, are difficult to project and model, and not always fully considered in current impact assessments.

- Some critical processes (e.g. extreme events in climate models or disturbances in forest ecosystem dynamics) are still difficult to simulate and thus are lacking in most available impact studies.

- All these simplifications in simulated impact assessments suggest that the range of possible impacts has so far been underestimated.

- Individual climate change impact studies should not be uncritically used for decision making without reflection on possible shortcomings in system understanding, model uncertainty and other assumptions made.

In order to properly interpret climate change impact projections, considerable expert knowledge and scientific understanding is still necessary. To interpret and communicate the complex information is a challenge to scientists: Simple but not simplistic messages are needed!

\subsection{How to communicate complex climate change impacts on forests and related uncertainties}

Communication of climate change projections and impacts and the related uncertainties to non-scientific audiences is an important contributor towards facilitating adaptation. Recent research (Blennow et al., 2012; Yousefpour et al., 2013) has found that forest managers' beliefs about climate change influences their decisions. Wachinger et al. (2013) show that personal experience of a natural hazard and trust-or lack of trust-in authorities and experts have the most substantial impact on risk perception and consequently on decision making. This underlines the importance of communicating observed and projected impacts to different audiences, from high level decision makers and national forest governance organisations, to private forest owners and forest companies. However it is difficult to communicate complex issues such as model uncertainties without diluting the message. Many studies have appeared in recent times about effective communication of uncertainties to policy makers, often focussing on the language used (Maslin, 2013; Budescu et al., 2011; Sterman, 2011). One approach to tackling the communication problem is to place the emphasis on uncertainty on the date by which things will happen, rather than onto whether they will happen at all (Maslin, 2013). For example, Joshi et al. (2011) showed that a rise in global mean temperature of $2{ }^{\circ} \mathrm{C}$ will be reached sometime between 2040 and 2100 depending on which emissions scenario and climate model is used.

Communication to decision makers has to be brief and simple to be effective. Whereas presenting climate change uncertainties in a simple way can be difficult, it is, however, still important to highlight them. Kangas and Kangas (2004) have cautioned against ignoring uncertainty and to ensure it is taken into account in decision making. Therefore when making statements or judgements in the type of forum which does not allow for elaboration, it is helpful if scientists are prepared to provide a traceable account of how this judgement was arrived at for those who seek more information (Mastrandrea and Mach, 2011).

At the regional level, different communication mechanisms are necessary with forest practitioners at forest administrations as the key target (Lawrence and Marzano, 2013). This target audience needs information with the aim of developing support measures and preparing of recommendations towards forest managers at a practical level. An important question for forest managers is when management needs to be adjusted to expected changes (Yousefpour et al., 2012). Blennow et al. (2012) conducted a study, which showed that strength of belief in climate change whether through direct experience or other learning mechanisms, accurately predicted adaptation to climate change and was more significant than socioeconomic factors. Uncertainties will always be present and postponing action until they are eliminated is not an appropriate response. Brunette et al. (2014) present an option value approach to support the decision when to change a tree species under climate change and discuss the importance of the timing of the species change from an economic point of view. However these decisions should be solidly based on detailed knowledge about probable outcomes of climate change for forests (Yousefpour et al., 2012). Forest decision makers already have experience in dealing with similar uncertainty in the type of long term thinking which is required with respect to price uncertainty etc. Thus, handling uncertainties in the context of climate change is not an unknown challenge.

\section{Synthesis and conclusions}

Most impact studies that were carried out since the Fourth IPCC Assessment Report in Europe are based on scenarios that projected relatively modest climate change compared to the newer RCP8.5 scenario. Recent evidence shows that without rapid policy action, changes in climate could be more serious. Furthermore, observations already document (i) tree movements (but species will be unable to keep up with projected climate change over the current century) and (ii) changes in growth, which exceed the projections of many impact assessment models. Climate change may impact forests in ways that are partly opposing and therefore can require adaptation activities that are difficult to design and to plan. On the one hand European forests are facing gradual changes such as the change of biomes of major tree species and changes in productivity. On the other, forests are likely to be more and more exposed to extreme events such as the increased risk of fire and drought and, partly linked to that, the spread of pests and diseases. Both gradual changes and extreme events can either have cumulative effects or can counterbalance each other. The latter would be the case if the observed increase of productivity in Northern Europe is counterbalanced by the effect of the expected increasing impact of storms and insects in Nordic countries. Cumulative effects can already be seen in Southern Europe, where a gradual decrease in productivity combined with extreme droughts and increased fire risk leads to increased tree mortality and even a replacement of forests by other vegetation types. The speed of evolving changes such as range shifts of tree species should be carefully studied, as it will have consequences for the planning of adaptation strategies. Newer modelling studies which include tree species migration suggest that standard applications of range shift models largely overestimate the speed of such a change (Meier et al., 2012). The implications for tree physiology of increased atmospheric $\mathrm{CO}_{2}$ concentration combined with climate change also remain unclear and this strongly increases the uncertainty of forest model projections. 
When interpreting climate scenario projections, more than one average climate scenario needs to be studied. Impact assessments have to consider appropriate climate variables that are critical for tree growth and survival. Uncertainties around climate change impacts in European forests appear to be particularly large in areas where the most adverse effects are likely (e.g. in the Mediterranean). This underlines that uncertainty increases with the severity of the change we are projecting for our climate (Knutti and Sedlacek, 2013). Simulation studies that operate with overly simplistic assumptions should not be used as a basis for guiding forest management decision making. Therefore scientists have an important role in communicating knowledge about climate change impacts and uncertainties to practitioners and policy makers.

Based on this synthesis, planning adaptation strategies seems to be a complex and challenging task, as gradual changes and the more catastrophic impacts of extreme events require different activities. An anticipated long-term change in suitability of a tree species may require change to a more drought- and heat adapted species. However, in the transition phase, extremes may occur in both directions (hot and cold), which make a pro-active introduction of e.g. Mediterranean oaks in Central Europe on larger areas impossible. Adapting to an expected decrease of productivity by introducing exotic species with higher productivity has been successfully conducted with Douglas fir as replacement for Norway spruce in some parts of Europe, but we need additional experiences with other species also under unfavourable site conditions. Adapting forests to extreme events is particularly difficult where drought is concerned, as the increasing length of dry periods in the future climate may lead to conditions in parts of Europe where almost no tree species will be able to survive. Reducing tree density in arid areas to enhance water availability for the remaining trees may be efficient, but it is a costly measure in a region where the economic output of forestry is generally low. Adapting forests to extreme storm events is - outside Great Britain and Ireland with already existing particular storm adapted management strategies - an exception, and requires measures such as limiting tree height that are unpopular and against the dominating "close-to-nature" forestry with long rotation periods in Central Europe.

Despite intensive research over two decades, we cannot accurately forecast emissions and what the climate in Europe will be like later this century. It is unlikely that this situation will change anytime soon. Regional impact studies therefore need to analyse multiple climate scenarios to explore a broad range of possible developments. Impact assessments contain simplifications, and with our improving system understanding it is important to interpret them adequately. Growth decline and mortality are especially triggered by extreme events and it is crucial to consider how disturbance impacts could alter the results derived from simple models that lack a proper representation of extreme events and disturbances. The challenge for forest management is how to cope with the observed and modelled trends and their associated uncertainties in adaptive forest management. Strategies that enhance ecosystem resilience are recommended, as are strategies which increase the flexibility of making future management changes, as required by realized climate change trends.

\section{Acknowledgements}

The study was supported by the European Community's Seventh Framework Programme under the project MOTIVE ("Models for adaptive forest management"), grant agreement 226544.

\section{Appendix A. Supplementary material}

Supplementary material related to this article can be found at http://dx.doi.org/10.1016/j.jenvman.2014.07.030.

\section{References}

Adams, H.D., Guardiola-Claramonte, M., Barron-Gafford, G.A., et al., 2009. Temperature sensitivity of drought-induced tree mortality portends increased regiona die-off under global-change-type drought. Proc. Natl. Acad. Sci. U.S.A. 106 7063-7066.

Allen, C.D., Breshears, D.D., 1998. Drought-induced shift of a forest-woodland ecotone: rapid landscape response to climate variation. Proc. Natl. Acad. Sci. U.S.A. 95, 14839-14842.

Allen, C.D., Macalady, A.K., Chenchouni, H., Bachelet, D., McDowell, N. Vennetier, M., Kitzberger, T., Rigling, A., Breshears, D.D., Hogg, E.H., Gonzalez, P., Fensham, R., Zhang, Z., Castro, J., Demidova, N., Lim, J.-H., Allard, G. Running, S.W., Semerci, A., Cobb, N., 2010. A global overview of drought and heat-induced tree mortality reveals emerging climate change risks for forests. For. Ecol. Manag. 259, 660-684.

Anderegg, W.R.L., Kane, J.M., Anderegg, L.D.L., 2013. Consequences of widespread tree mortality triggered by drought and temperature stress. Nat. Clim. Change 3, 30-36.

Araujo, M.B., New, M., 2007. Ensemble forecasting of species distributions. Trends Ecol. Evol. 22, 42-47.

Barriopedro, D., Fischer, E.M., Luterbacher, J., Trigo, R., Garcia-Herrera, R., 2011. The hot summer of 2010: redrawing the temperature record map of Europe. Science 332 (6026), 220-224.

Battipaglia, G., Saurer, M., Cherubini, P., Calfapietra, C., McCarthy, H.R., Norby, R.J., Francesca Cotrufo, M., 2013. Elevated CO2 increases tree-level intrinsic water use efficiency: insights from carbon and oxygen isotope analyses in tree rings across three forest FACE sites. New Phytol. 197, 544-554.

Bigler, C., Bräker, O., Bugmann, H., Dobbertin, M., Rigling, A., 2006. Drought as an inciting mortality factor in scots pine stands of the Valais, Switzerland. Ecosystems 9, 330-343.

Blennow, K., Persson, J., Tomé, M., Hanewinkel, M., 2012. Climate change: believing and seeing implies adapting. PLoS ONE 7 (11), e50182.

Boisvenue, C., Running, S.W., 2006. Impacts of climate change on natural forest productivity - evidence since the middle of the 20th century. Glob. Change Biol. 12, 862-882.

Bolte, A., Ammer, C., Löf, M., Madsen, P., Nabuurs, G.-J., Schall, P., Spathelf, P., Rock, J. 2009. Adaptive forest management in central Europe: climate change impacts, strategies and integrative concept. Scand. J. For. Res. 24, 473-482.

Bontemps, J.-D., Hervé, J.-C., Dhôte, J.-F., 2009. Long-term changes in forest productivity: a consistent assessment in even-aged stands. For. Sci. 55, 549-564.

Bontemps, J.-D., Hervé, J.-C., Dhôte, J.-F., 2010. Dominant radial and height growth reveal comparable historical variations for common beech in north-eastern France. For. Ecol. Manag. 258, 1455-1463.

Brunette, M., Costa, S., Lecocq, F., 2014. Economics of species change subject to risk of climate change and increasing information: a (quasi-)option value analysis. Ann. Forest Sci. 71.

Budescu, D.V., Por, H.H., Broomell, S.B., 2011. Effective communication of uncertainty in the IPCC reports. Clim. Change 113 (2), 181-200.

Buisson, L., Thuiller, W., Casajus, N., Lek, S., Grenouillet, G., 2010. Uncertainty in ensemble forecasting of species distribution. Glob. Change Biol. 16, 1145-1157.

Campioli, M., Vincke, C., Jonard, M., Kin, V., Demarée, G., Ponette, Q., 2012. Current status and predicted impact of climate change on forest production and biogeochemistry in the temperate oceanic European zone: review and prospects for Belgium as a case study. J. For. Res. 17, 1-18.

Carvalho, A.C., Carvalho, A., Martins, H., Marques, C., Rocha, A., Borrego, C. Viegas, D.X., Miranda, A.I., 2011. Fire weather risk assessment under climate change using a dynamical downscaling approach. Environ. Model. Softw. 26 (9), $1123-1133$

Charru, M., Seynave, I., Morneau, F., Bontemps, J.-D., 2010. Recent changes in forest productivity: an analysis of national forest inventory data for common beech (Fagus sylvatica L.) in north-eastern France. For. Ecol. Manag. 260, 864-874.

Chatry, C., Le Quentrec, M., Laurens, D., Le Gallou, J.-Y., Lafitte, J.-J., Creuchet B., 2010. Rapport de la mission interministérielle 'Changement climatique et extension des zones sensibles aux feux de forêts. CGAER- CGEDD-IGA, July 2010. 89 p + annexes.

Christensen, J.H., Hewitson, B., Busuioc, A., Chen, A., Gao, X., Held, I., Jones, R. Kolli, R.K., Kwon, W.-T., Laprise, R., Rueda, V.M., Mearns, L., Menéndez, C.G. Räisänen, J., Rinke, A., Sarr, A., Whetton, P., 2007. Regional climate projections. In: Solomon, S., Qin, D., Manning, M., Chen, Z., Marquis, M., Averyt, K.B. Tignor, M., Miller, H.L. (Eds.), Climate Change 2007: The Physical Science Basis. Contribution of Working Group I to the Fourth Assessment Report of the Intergovernmental Panel on Climate Change. Cambridge University Press, Cambridge, United Kingdom and New York, NY, USA, pp. 847-940.

Choat, B., Jansen, S., Brodribb, T.J., Cochard, H., Delzon, S., et al., 2012. Globa convergence in the vulnerability of forests to drought Nature 491, 752-755.

Ciais, P., Reichstein, M., Viovy, N., Granier, A., Ogée, J., Allard, V., Valentini, R., 2005. Europe-wide reduction in primary productivity caused by the heat and drought in 2003. Nature 437 (7058), 529-533. 
Coumou, D., Robinson, A., 2013. Historic and future increase in the global land area affected by monthly heat extremes. Environ. Res. Lett. 8 (3), 034018.

Dale, V., Joyce, L., McNulty, S., Neilson, R., Ayres, M., Flannigan, M., Hanson, P., Irland, L., Lugo, A., Peterson, C.J., Simberloff, D., Swanson, F., Stocks, B., Wotton, M., 2001. Climate change and forest disturbances. Bioscience 51, $723-734$

Dantec, C.F., Vitasse, Y., Bonhomme, M., Louvet, J.-M., Kremer, A., Delzon, S., 2014 Chilling and heat requirements for leaf unfolding in European beech and sessile oak populations at the southern limit of their distribution range. Int. J. Biometeorol., 1-12. http://dx.doi.org/10.1007/s00484-014-0787-7.

Delzon, S., Urli, M., Samalens, J.-C., Lamy, J.-B., Lischke, H., Sin, F., Zimmermann, N.E. Porté, A.J., 2013. Field evidence of colonisation by Holm oak, at the northern margin of its distribution range, during the Anthropocene period. PLOS ONE 8 e80443.

De Kauwe, M.G., Medlyn, B.E., Zaehle, S., Walker, A.P., Dietze, M.C., Hickler, T., Jain, A.K., Luo, Y., Parton, W.J., Prentice, C., Smith, B., Thornton, P.E., Wang, S., Wang, Y.-P., Wårlind, D., Weng, E.S., Crous, K.Y., Ellsworth, D.S., Hanson, P.J. Seok-Kim, H., Warren, J.M., Oren, R., Norby, R.J., 2013. Forest water use and water use efficiency at elevated CO2: a model-data intercomparison at two contrasting temperate forest FACE sites. Glob. Change Biol. 19, 1759-1779.

Desprez-Loustau, M.-L., Marcais, B., Nageleisen, L.-M., Piou, D., Vannini, A., 2006. Interactive effects of drought and pathogens in forest trees. Ann. For. Sci. 63, 597-612.

European Environment Agency (EEA), 2012. Climate Change, Impacts and Vulnerability in Europe 2012 - an Indicator based Report. European Environment Agency, Denmark, 304pp.

Field, C.B., Barros, V., Stocker, T.F., Oin, D., Dokken, D.J., Ebi, K.L., Mastrandrea, M.D. Mach, K.J., Plattner, G.-K., Allen, S.K., Tignor, M., Midgley, P.M. (Eds.), 2012. Managing the Risks of Extreme Events and Disasters to Advance Climate Change Adaptation. A Special Report of Working Groups I and II of the Intergovernmental Panel on Climate Change. Cambridge University Press, Cambridge, UK, and New York, USA.

Fink, A.H., Brücher, T., Ermert, V., Krüger, A., Pinto, J.G., 2009. The European storm Kyrill in January 2007: synoptic evolution, meteorological impacts and some considerations with respect to climate change. Nat. Hazards Earth Syst. Sci. 9, 405-423.

Fischer, R., Lorenz, M., Köhl, M., Mues, V., Granke, O., Iost, S., van Dobben, H. Reinds, G., de Vries, W., 2010. The Condition of Forests in Europe. 2010 Executive Report. ICP Forests and European Commission, Hamburg and Brussels, 21 pp.

Fischer, A., Marshall, P., Camp, A., 2013. Disturbances in deciduous temperate forest ecosystems of the northern hemisphere: their effects on both recent and future forest development. Biodivers. Conserv. 22, 1863-1893.

Fischer, E.M., Schär, C., 2010. Consistent geographical patterns of changes in highimpact European heatwaves. Nat. Geosci. 3 (6), 398-403.

Fitzgerald, J., Lindner, M. (Eds.), 2013. Adapting to Climate Change in European Forests - Results of the MOTIVE Project. Pensoft Publishers, Sofia, $108 \mathrm{pp}$

Flint, L., Flint, A., 2012. Downscaling future climate scenarios to fine scales for hydrologic and ecological modeling and analysis. Ecol. Process. 1, 2.

Fowler, H.J., Blenkinsop, S., Tebaldi, C., 2007. Linking climate change modelling to impacts studies: recent advances in downscaling techniques for hydrologica modelling. Int. J. Climatol. 27, 1547-1578.

Gardiner, B., Shuck, A., Schelhaas, M.J., Orazio, C., Blennow, K., Nicoll, B. (Eds.), 2012 Living with Storm Damage to Forests: What Science Can Tell Us. European Forest Institute Joensuu, Finland (129 pp.).

Guisan, A., Zimmermann, N.E., 2000. Predictive habitat distribution models in ecology. Ecol. Model. 135 (2-3), 147-186.

Hallegatte, S., 2009. Strategies to adapt to an uncertain climate change. Glob. Environ. Change 19, 240-247.

Hanewinkel, M., Cullmann, D.A., Schelhaas, M.J., Nabuurs, G.J., Zimmermann, N.E., 2013. Climate change may cause severe loss in the economic value of European forest land. Nat. Clim. Change 3, 203-207.

Hanewinkel, M., Hummel, S., Albrecht, A., 2011. Assessing natural hazards in forestry for risk management: a review. Eur. J. For. Res. 130, 329-351.

Haarsma, R.J., Hazeleger, W., Severijns, C., Vries, H.D., Sterl, A., Bintanja, R. Oldenborgh, G.J.V., Brink, H.W.V.D., 2013. More hurricanes to hit Western Europe due to global warming. Geophys. Res. Lett. 40, 1783-1788.

Hlásny, T., Barcza, Z., Fabrika, M., Balázs, B., Churkina, G., Pajtík, J., Sedmák, R. Turčáni, M., 2012. Climate change impacts on growth and carbon balance of forests in Central Europe. Clim. Res. 47, 219-236.

Holsten, A., Dominic, A.R., Costa, L., Kropp, J.P., 2013. Evaluation of the performance of meteorological forest fire indices for German federal states. For. Ecol. Manag. 287, 123-131.

Jactel, H., Petit, J., Desprez-Loustau, M.-L., Delzon, S., Piou, D., Battisti, A., Koricheva, J., 2012. Drought effects on damage by forest insects and pathogens: a meta-analysis. Glob. Change Biol. 18, 267-276.

Jenkins, J.C., Birdsey, R.A., Pan, Y., 2001. Biomass and NPP estimation for the midAtlantic region (USA) using plot-level inventory data. Ecol. Appl. 11, 1174-1193.

Jones, R.N., 2000. Managing uncertainties in climate change projections: issues for impact assessment. Clim. Change 45 (3-4), 403-419.

Jones, P., Moberg, A., 2003. Hemispheric and large-scale surface air temperature variations: an extensive revision and an update to 2001. J. Clim. 16, 206-223.

Joshi, M., Hawkins, E., Sutton, R., Lowe, J., Frame, D., 2011. Projections of when temperature change will exceed $2^{\circ} \mathrm{C}$ above pre-industrial levels. Nat. Clim. Change 1, 407-412.
Jump, A.S., Hunt, J.M., Peñuelas, J., 2006. Rapid climate change-related growth decline at the southern range edge of Fagus sylvatica. Glob. Change Biol. 12, 2163-2174.

Kangas, A.S., Kangas, J., 2004. Probability, possibility and evidence: approaches to consider risk and uncertainty in forest decision analysis. For. Policy Econ. 6, $169-188$.

Kahle, H.-P., Karjalainen, T., Schuck, A., Ågren, G.I., Kellomäki, S., Mellert, K., Prietzel, J., Rehfuess, K.E., Spiecker, H., 2008. Causes and Consequences of Forest Growth Trends in Europe - Results of the RECOGNITION Project. European Forest Institute Research Report 21. Brill, Leiden.

Kearney, M., Porter, W., 2009. Mechanistic niche modelling: combining physiological and spatial data to predict species' ranges. Ecol. Lett. 12, 334-350.

Keenan, T.F., Hollinger, D.Y., Bohrer, G., Dragoni, D., Munger, J.W., Schmid, H.P., Richardson, A.D., 2013. Increase in forest water-use efficiency as atmospheric carbon dioxide concentrations rise. Nature 499, 324-327.

Kint, V., Aertsen, W., Campioli, M., Vansteenkiste, D., Delcloo, A., Muys, B., 2012. Radial growth change of temperate tree species in response to altered regional climate and air quality in the period 1901-2008. Clim. Change 115 (2), 343-363.

Kjellström, E., Nikulin, G., Hansson, U.L.F., Strandberg, G., Ullerstig, A., 2011. 21st century changes in the European climate: uncertainties derived from an ensemble of regional climate model simulations. Tellus A 63, 24-40.

Klapwijk, M.J., Ayres, M.P., Battisti, A., Larsson, S., 2011. Assessing the impact of climate change on outbreak potential. In: Barbosa, P., Letourneau, D.K. Agrawal, A.A. (Eds.), Front Matter, in Insect Outbreaks Revisited. John Wiley \& Sons, Ltd, Chichester, UK.

Knoke, T., Stimm, B., Ammer, C., Moog, M., 2005. Mixed forests reconsidered: a forest economics contribution on an ecological concept. For. Ecol. Manag. 213, $102-116$.

Knutti, R., Sedlacek, J., 2013. Robustness and uncertainties in the new CMIP5 climate model projections. Nat. Clim. Change 3, 369-373.

Koehl, M., Hildebrandt, R., Olschofsky, K., Koehler, R., Roetzer, T., Mette, T., Pretzsch, H., Koethke, M., Dieter, M., Abiy, M., Makeschin, F., Kenter, B., 2010. Combating the effects of climatic change on forests by mitigation strategies. Carbon Balance Manag. 2010 (5), 8.

Kolström, M., Lindner, M., Vilén, T., Maroschek, M., Seidl, R., Lexer, M.J., Netherer, S., Kremer, A., Delzon, S., Barbati, A., Marchetti, M., Corona, P., 2011. Reviewing the science and implementation of climate change adaptation measures in European forestry. Forests 2, 961-982.

Koutsias, N., Arianoutsou, M., Kallimanis, A.S., Mallinis, G., Halley, J.M., Dimopoulos, P., 2012. Where did the fires burn in Peloponnisos, Greece the summer of 2007? Evidence for a synergy of fuel and weather. Agric. For. Meteorol. 156, 41-53.

Krupa, S.V., Kickert, R.N., 1989. The Greenhouse effect: impacts of ultraviolet-B (UVB) radiation, carbon dioxide (CO2), and ozone (O3) on vegetation. Environ. Pollut. 61, 263-393.

Lavalle, C., Micale, F., Durrant Houston, T., Camia, A., Hiederer, R., Lazar, C., Conte, C., Amatulli, G., Genovese, G., 2009. Climate change in Europe. 3. Impact on agriculture and forestry. A review. Agron. Sustain. Dev. 29 (3), 433-446.

Lawrence, A., Marzano, M., 2013. Is the private forest sector adapting to climate change? A study of forest managers in north Wales. Ann. For. Sci. 71, 291-300.

Leckebusch, G.C., Weimer, A., Pinto, J.G., Reyers, M., Speth, P., 2008. Extreme wind storms over Europe in present and future climate: a cluster analysis approach. Meteorol. Z. 17, 67-82.

Lenoir, J., Gegout, J.C., Marquet, P.A., De Ruffray, P., Brisse, H., 2008. A significant upward shift in plant species optimum elevation during the 20th century. Science 320, 1768-1771.

Le Treut, H., Somerville, R., Cubasch, U., Ding, Y., Mauritzen, C., Mokssit, A., Peterson, T., Prather, M., 2007. Historical overview of climate change. In: Solomon, S., Qin, D., Manning, M., Chen, Z., Marquis, M., Averyt, K.B., Tignor, M., Miller, H.L. (Eds.), Climate Change 2007: the Physical Science Basis. Contribution of Working Group I to the Fourth Assessment Report of the Intergovernmental Panel on Climate Change. Cambridge University Press, Cambridge, United Kingdom and New York, NY, USA.

Lindner, M., Maroschek, M., Netherer, S., Kremer, A., Barbati, A., Garcia-Gonzalo, J., Seidl, R., Delzon, S., Corona, P., Kolström, M., Lexer, M.J., Marchetti, M., 2010. Climate change impacts, adaptive capacity, and vulnerability of European forest ecosystems. For. Ecol. Manag. 259, 698-709.

Loehle, C., LeBlanc, D., 1996. Model-based assessments of climate change effects on forests: a critical review. Ecol. Model. 90, 1-31.

Maslin, M., 2013. Cascading uncertainty in climate change models and its implications for policy. Geogr. J. 179 (3), 264-271.

Mastrandrea, M., Mach, K., 2011. Treatment of uncertainties in IPCC Assessment Reports: past approaches and considerations for the Fifth Assessment Report. Clim. Change 108, 659-673.

Meier, E.S., Lischke, H., Schmatz, D.R., Zimmermann, N.E., 2012. Climate, competition and connectivity affect future migration and ranges of European trees. Global Ecol. Biogeogr. 21, 164-178.

Metzger, M.J., Bunce, R.G.H., Jongman, R.H.G., Mücher, C.A., 2005. A climatic stratification of the environment of Europe. Global Ecol. Biogeogr. 14, 549-563.

Millar, C.I., Stephenson, N.L., Stephens, S.L., 2007. Climate change and forests of the future: managing in the face of uncertainty. Ecol. Appl. 17, 2145-2151.

Moraal, L.G., Jagers op Akkerhuis, G.A.J.M., 2011. Changing patterns in insect pests on trees in The Netherlands since 1946 in relation to human induced habitat 
changes and climate factors - an analysis of historical data. For. Ecol. Manag. 261, 50-61.

Morice, C.P., Kennedy, J.J., Rayner, N.A., Jones, P.D., 2012. Quantifying uncertainties in global and regional temperature change using an ensemble of observational estimates: the HadCRUT4 dataset. J. Geophys. Res. 117 (D8), 27.

Moriondo, M., Good, P., Durao, R., Bindi, M., Giannakopoulos, C., Corte-Real, J., 2006 Potential impact of climate change on fire risk in the Mediterranean area. Clim. Res. 31, 85-95.

Moss, R.H., Edmonds, J.A., Hibbard, K.A., Manning, M.R., Rose, S.K., van Vuuren, D.P., Carter, T.R., Emori, S., Kainuma, M., Kram, T., Meehl, G.A., Mitchell, J.F.B., Nakicenovic, N., Riahi, K., Smith, S.J., Stouffer, R.J., Thomson, A.M., Weyant, J.P., Wilbanks, T.J., 2010. The next generation of scenarios for climate change research and assessment. Nature 463, 747-756.

Nakicenovic, N., Swart, R. (Eds.), 2000. Emissions Scenarios. Cambridge University Press, Cambridge, U.K.

Ogden, A.E., Innes, J.L., 2009. Application of structured decision making to an assessment of climate change vulnerabilities and adaptation options for sustainable forest management. Ecol. Soc. 14.

Orlowsky, B., Seneviratne, S.I., 2012. Global changes in extreme events: regional and seasonal dimension. Clim. Change 110 (3-4), 669-696.

Peltola, H., Kellomäki, S., Väisänen, H., 1999. Model computations of the impact of climatic change on the windthrow risk of trees. Clim. Change $41,17-36$.

Penuelas, J., Boada, M., 2003. A global change-induced biome shift in the Montseny Mountains (NE Spain). Glob. Change Biol. 9, 131-140.

Peters, G.P., Andrew, R.M., Boden, T., Canadell, J.G., Ciais, P., Le Quere, C., Marland, G., Raupach, M.R., Wilson, C., 2013. The challenge to keep global warming below $2^{\circ}$ C. Nat. Clim. Change 3, 4-6.

Peterson, D.L., Millar, C.I., Joyce, L.A., Furniss, M.J., Halofsky, J.E., Neilson, R.P., Morelli, T.L., 2011. Responding to Climate Change in National Forests: a Guidebook for Developing Adaptation Options In, Gen. Tech. Rep. U.S. Department of Agriculture, Forest Service, Pacific Northwest Research Station, Portland, OR, USA, p. 109.

Piao, S., Sitch, S., Ciais, P., Friedlingstein, P., Peylin, P., Wang, X., Ahlström, A., Anav, A., Canadell, J.G., Cong, N., Huntingford, C., Jung, M., Levis, S., Levy, P.E., Li, J., Lin, X., Lomas, M.R., Lu, M., Luo, Y., Ma, Y., Myneni, R.B., Poulter, B., Sun, Z., Wang, T., Viovy, N., Zaehle, S., Zeng, N., 2013. Evaluation of terrestrial carbon cycle models for their response to climate variability and to CO2 trends. Glob. Change Biol. 19 (7), 2117-2132.

Piao, S., Wang, X., Ciais, P., Zhu, B., Wang, T.A.O., Liu, J.I.E., 2011. Changes in satellitederived vegetation growth trend in temperate and boreal Eurasia from 1982 to 2006. Glob. Change Biol. 17, 3228-3239.

Poulter, B., Frank, D.C., Hodson, E.L., Zimmermann, N.E., 2011. Impacts of land cover and climate data selection on understanding terrestrial carbon dynamics and the CO2 airborne fraction. Biogeosciences 8, 1617-1642.

Pryor, S.C., Barthelmie, R.J., Clausen, N.E., Drews, M., MacKellar, N., Kjellstrom, E., 2012. Analyses of possible changes in intense and extreme wind speeds over Northern Europe under climate change scenarios. Clim. Dyn. 38, 189-208.

Rahmstorf, S., Coumou, D., 2011. Increase of extreme events in a warming world. Proc. Natl. Acad. Sci. U.S.A. 108, 17905-17909.

Reyer, C., 2013. The Cascade of Uncertainty in Modelling Forest Ecosystem Responses to Environmental Change and the Challenge of Sustainable Resource Management. Mathematisch-Naturwissenschaftliche Fakultät II Humboldt Universität, Berlin, p. 168.

Reyer, C., Lasch-Born, P., Suckow, F., Gutsch, M., Murawski, A., Pilz, T., 2013a. Projections of regional changes in forest net primary productivity for different tree species in Europe driven by climate change and carbon dioxide. Ann. For. Sci. 71, $211-225$.

Reyer, C., Leuzinger, S., Rammig, A., Wolf, A., Bartholomeus, R.P., Bonfante, A., De Lorenzi, F., Dury, M., Gloning, P., Abou Jaoudé, R., Klein, T., Kuster, T.M., Martins, M., Niedrist, F., Riccardi, M., Wohlfahrt, G., De Angelis, P., de Dato, G., François, L., Menzel, A., Pereira, M., 2013b. A plant's perspective of extremes: terrestrial plant responses to changing climatic variability. Glob. Change Biol. 19, 75-89.

Rigling, A., Bigler, C., Eilmann, B., Feldmeyer-Christe, E., Gimmi, U., Ginzler, C., Graf, U., Mayer, P., Vacchiano, G., Weber, P., Wohlgemuth, T., Zweifel, R., Dobbertin, M., 2013. Driving factors of a vegetation shift from Scots pine to pubescent oak in dry Alpine forests. Glob. Change Biol. 19, 229-240.

Robinet, C., Roques, A., 2010. Direct impacts of recent climate warming on insect populations. Integr. Zool. 5, 132-142.

Rogelj, J., Meinshausen, M., Knutti, R., 2012. Global warming under old and new scenarios using IPCC climate sensitivity range estimates. Nat. Clim. Change 2, $248-253$.

Ruffault, J., Martin-StPaul, N.K., Rambal, S., Mouillot, F., 2013. Differential regional responses in drought length, intensity and timing to recent climate changes in a Mediterranean forested ecosystem. Clim. Change 117, 103-117.

Rummukainen, M., 2012. Changes in climate and weather extremes in the 21st century. WIREs Clim. Change 3, 115-129.

Sánchez-Salguero, R., Navarro-Cerrillo, R.M., Camarero, J.J., Fernández-Cancio, Á., 2012. Selective drought-induced decline of pine species in southeastern Spain. Clim. Change 113, 767-785.

San-Miguel-Ayanz, J., Moreno, J.M., Camia, A., 2013. Analysis of large fires in European Mediterranean landscapes: lessons learned and perspectives. For. Ecol. Manag. 294, 11-22.
Sarris, D., Christodoulakis, D., Körner, C., 2011. Impact of recent climatic change on growth of low elevation eastern Mediterranean forest trees. Clim. Change 106, 203-223.

Schneider, S.H., 1983. CO2, climate and society: a brief overview. In: Chen, R.S., Boulding, E.M., Schneider, S.H. (Eds.), Social Science Research and Climatic Change: An Interdisciplinary Appraisal. D. Reidel Publishing, Dordrecht, The Netherlands, pp. 9-15.

Seidl, R., Fernandes, P.M., Fonseca, T.F., Gillet, F., Jönsson, A.M., Merganicová, K., Netherer, S., Arpaci, A., Bontemps, J.D., Bugmann, H., González-Olabarria, J.R. Lasch, P., Meredieu, C., Moreira, F., Schelhaas, M.J., Mohren, F., 2011a. Modelling natural disturbances in forest ecosystems: a review. Ecol. Model. 222, 903-924.

Seidl, R., Schelhaas, M.J., Lexer, M.J., 2011b. Unraveling the drivers of intensifying forest disturbance regimes in Europe. Global Change Biol. 17, 2842-2852.

Seneviratne, S.I., Nicholls, N., Easterling, D., Goodess, C.M., Kanae, S., Kossin, J., Luo, Y., Marengo, J., McInnes, K., Rahimi, M., Reichstein, M., Sorteberg, A. Vera, C., Zhang, X., 2012. Changes in climate extremes and their impacts on the natural physical environment. In: Field, C.B., Barros, V., Stocker, T.F., Qin, T., Dokken, D.J., Ebi, K.L., Mastrandrea, M.D., Mach, K.J., Plattner, G.-K., Allen, S.K., Tignor, M., Midgley, P.M. (Eds.), Managing the Risks of Extreme Events and Disasters to Advance Climate Change Adaptation. A Special Report of Working Groups I and II of the Intergovernmental Panel on Climate Change (IPCC) Cambridge University Press, Cambridge, UK, and New York, NY, USA pp. $109-230$.

Seppälä, R., Buck, A., Katila, P. (Eds.), 2009. Adaptation of Forests and People to Climate Change. A Global Assessment Report. IUFRO World Series, vol. 22. Helsinki. 224 pp.

Solomon, S., Qin, D., Manning, M., Chen, Z., Marquis, M., Averyt KBTignor, M., Miller, H.L. (Eds.), 2007. Climate Change 2007: The Physical Science Basis. Contribution of Working Group I to the Fourth Assessment Report of the Intergovernmental Panel on Climate Change. Cambridge University Press, Cambridge, United Kingdom and New York, NY, USA.

Spathelf, P., van der Maaten, E., van der Maaten-Theunissen, M., Campioli, M. Dobrowolska, D., 2014. Climate change impacts in European forests: the expert views of local observers. Ann. For. Sci. 71, 131-137.

Spiecker, H., Mielikäinen, K., Köhl, M., 1996. Growth Trends in European Forests Studies from 12 Countries. European Forest Institute Research Report; no. 5. Springer, Berlin.

Spiecker, H., 2003. Silvicultural management in maintaining biodiversity and resistance of forests in Europe-temperate zone. J. Environ. Manag. 67, 55-65.

Spittlehouse, D.L., Stewart, R.B., 2003. Adaptation to climate change in forest management. J. Ecosyst. Manag. 4, 1-11.

Sterman, J.D., 2011. Communicating climate change risks in a skeptical world. Clim. Change 108 (4), 811-826.

Stephenson, N.L., 1990. Climatic control of vegetation distribution: the role of the water balance. Am. Nat. 135, 649-670.

Sturrock, R.N., Frankel, S.J., Brown, A.V., Hennon, P.E., Kliejunas, J.T., Lewis, K.J., Worrall, J.J., Woods, A.J., 2011. Climate change and forest diseases. Plant Pathol. 60, 133-149.

Turc, L., 1963. Evaluation des besoins en eau d'irrigation, évapotranspiration potentielle, formulation simplifié et mise à jour. Ann. Agron. 12, 13-49.

Ulbrich, U., Leckebusch, G.C., Pinto, J.G., 2009. Extra-tropical cyclones in the present and future climate: a review. Theor. Appl. Climatol. 96, 117-131.

Urli, M., Delzon, S., Couallier, V., Eyermann, A., García-Valdés, R., de Zavala, M.A., Porté, A.J., 2014. Rapid altitudinal shifts in tree species distribution in response to global change in two Iberian mountains. J. Veg. Sci. 25 (1), 147-159.

Urli, M., Porté, A.J., Cochard, H., Guengant, Y., Burlett, R., Delzon, S., 2013. Xylem embolism threshold for catastrophic hydraulic failure in angiosperm trees. Tree Physiol. 33, 672-683.

Usbeck, T., Wohlgemuth, T., Dobbertin, M., Pfister, C., Bürgi, A., Rebetez, M., 2010a. Increasing storm damage to forests in Switzerland from 1858 to 2007. Agric. For. Meteorol. 150, 47-55.

Usbeck, T., Wohlgemuth, T., Pfister, C., Volz, R., Beniston, M., Dobbertin, M., 2010b. Wind speed measurements and forest damage in Canton Zurich (Central Europe) from 1891 to winter 2007. Int. J. Climatol. 30, 347-358.

van Mantgem, P.J., Stephenson, N.L., Byrne, J.C., et al., 2009. Widespread increase of tree mortality rates in the western United States. Science 323, 521-524.

van Vuuren, D.P., Edmonds, J., Kainuma, M., Riahi, K., Thomson, A., Hibbard, K., Hurtt, G.C., Kram, T., Krey, V., Lamarque, J.F., Masui, T., Meinshausen, M. Nakicenovic, N., Smith, S.J., Rose, S.K., 2011. The representative concentration pathways: an overview. Clim. Change 109, 5-31.

Van Wagner, C.E., 1987. Development and Structure of a Canadian Forest Fire Weather Index System. Forestry Technical Report 35. Canadian Forestry Service, Ottawa.

Vayreda, J., Martinez-Vilalta, J., Gracia, M., Retana, J., 2012. Recent climate changes interact with stand structure and management to determine changes in tree carbon stocks in Spanish forests. Global Change Biol. 18 (3), 1028-1041.

Vicente-Serrano, S.M., Lasanta, T., Gracia, C., 2010. Aridification determines changes in forest growth in Pinus halepensis forests under semiarid Mediterranean climate conditions. Agric. For. Meteorol. 150, 614-628.

Wachinger, G., Renn, O., Begg, C., Kuhlicke, C., 2013. The risk perception Paradox-implications for governance and communication of natural hazards. Risk Anal. 33, 1049-1065.

Walker, W.E., Harremoës, P., Rotmans, J., van der Sluijs, J.P., van Asselt, M.B.A., Janssen, P., Krayer von Krauss, M.P., 2003. Defining uncertainty. A conceptual 
basis for uncertainty management in model based decision support. Integr. Assess. 4 (1), 5-17.

Walker, B., Salt, D., 2006. Resilience Thinking: Sustaining Ecosystems and People in a Changing World. Island Press, Washington, DC, USA.

WMO, . The Global Climate 2001-2010 - a Decade of Climate Extremes. Available online at: http://library.wmo.int/pmb_ged/wmo_1103_en.pdf. World Meteorological Organisation, Geneva (12.07.13.)

Yousefpour, R., Jacobsen, J.B., Thorsen, B.J., Meilby, H., Hanewinkel, M. Oehler, K., 2012. A review of decision-making approaches to handle uncertainty and risk in adaptive forest management under climate change. Ann. For. Sci. 69, 1-15.

Yousefpour, R., Temperli, C., Bugmann, H., Elkin, C., Hanewinkel, M., Meilby, H. Jacobsen, J.B., Thorsen, B.J., 2013. Updating beliefs and combining evidence in adaptive forest management under climate change: a case study of Norway spruce (Picea abies L. Karst) in the Black Forest, Germany. J. Environ. Manag. 122, 56-64.

Zhu, K., Woodall, C.W., Clark, J.S., 2012. Failure to migrate: lack of tree range expansion in response to climate change. Glob. Change Biol. 18 (3), 1042-1052.

Zimmermann, N.E. Yoccoz, N.G. Edwards Jr., T.C., Meier, E.S., Thuiller, W. Guisan, A., Schmatz, D.R., Pearman, P.B., 2009. Climatic extremes improve predictions of spatial patterns of tree species. Proc. Natl. Acad. Sci. U.S.A. 106, 19723-19728.

Zimmermann, N.E., Reyer, C., Lasch, P., Suckow, F., Poulter, B., Meier, E.S., 2011. MOTIVE Deliverable 2.4: Report on projected species and productivity shifts. Available online at: http://motive-project.net/files/DOWNLOAD2/MOTIVE D24_2011_PIK-WSL_final_small_2.pdf (last accessed 18.10.13.). 